San Jose State University

SJSU ScholarWorks

Master's Theses

Master's Theses and Graduate Research

1975

\title{
An annotated, multi-media bibliography of elementary and intermediate grade level materials in English and in English and Spanish on the Mexican American
}

Sharon Maureen Carranza

San Jose State University

Follow this and additional works at: https://scholarworks.sjsu.edu/etd_theses

\section{Recommended Citation}

Carranza, Sharon Maureen, "An annotated, multi-media bibliography of elementary and intermediate grade level materials in English and in English and Spanish on the Mexican American" (1975). Master's Theses. 3047.

DOI: https://doi.org/10.31979/etd.qt2z-7rne

https://scholarworks.sjsu.edu/etd_theses/3047

This Thesis is brought to you for free and open access by the Master's Theses and Graduate Research at SJSU ScholarWorks. It has been accepted for inclusion in Master's Theses by an authorized administrator of SJSU ScholarWorks. For more information, please contact scholarworks@sjsu.edu. 


\section{INFORMATION TO USERS}

This material was produced from a microfilm copy of the original document. While the most advanced technological means to photograph and reproduce this document have been used, the quality is heavily dependent upon the quality of the original submitted.

The following explanation of techniques is provicied to help you understand markings or patterns which may appear on this reproduction.

1. The sign or "target" for pages apparently lacking from the document photographed is "Missing Page(s)". If it was possible to obtain the missing page(s) or section, they are spliced into the film along with adjacent pages. This may have necessitated cutting thru an image and duplicating adjacent pages to insure you complete continuity.

2. When an image on the film is obliterated with a large rour 1 brack mark is an indication that the photographer suspected that the coni may have moved during exposure and thus cause a blurred image. You will find a good image of the page in the adjacent frame.

3. When a map, drawing or chart, etc., was part of the material being photographed the photographer followed a definite method in "sectioning" the material. It is customary to begin photoing at the upper left hand corner of a large sheet and to continue photoing from left to right in equal sections with a small overlap. If necessary, sectioning is continued again - beginning below the first row and continuing on until complete.

4. The majority of users indicate that the textual content is of greatest value, however, a somewhat higher quality reproduction could be made from "photographs" if essential to the understanding of the dissertation. Silver prints of "photographs" may be ordered at additional charge by writing the Order Department, giving the catalog number, title, author and specific pages you wish reproduced.

5. PLEASE NOTE: Some pages may have indistinct print. Filmed as received.

Xerox University Microfilms

300 North Zeeb Road

Ann Arbor, Michigan $\mathbf{4 8 1 0 6}$ 


\author{
MASTERS THESIS M-7913 \\ CARRANZA, Sharon Maureen \\ AN ANNÓTATED, MULT.I-MEDIA BIBI TOGRAPHY \\ OF ELEMENTARY AND INTERMEDIATE GRADE \\ LEVEL MATERIALS IN ENGLISH AND IN ENGLISH \\ AND SPANISH ON THE MEXICAN AMERICAN. \\ San Jose State University, M.A., 1975 \\ Library Science
}

Xerox University Microfilms, Ann Arbor, Michigan 48106

(C) Copyright by

SHARON MAUREEN CARRANZA

1975 


\author{
AN ANNOTATED, MULTI-MEDIA BIBLIOGRAPHY \\ OF ELEMENTARY AND INTERMEDIATE GRADE IEVEL \\ MATERIALS IN ENGLISH AND IN ENGLISH AND \\ SPANISH ON THE MEXICAN AMERICAN
}

\author{
A Research Paper \\ Presented to \\ the Faculty of the Department of Librarianship \\ San José State University
}

\author{
In Partial Fulfillment \\ of the Requirements for the Degree \\ Master of Arts
}

By

Sharon Maureen Carranza

May, 1975 


\title{
ABSTRACT
}

\begin{abstract}
AN ANNOTATED, MULTI-VIEDIA BIBLIOGRAPHY OF ELEMENTARY AND INTERMEDIATE GRADE LEVEI MATERIALS IN ENGLISH AND IN ENGLISH AND SPANISH ON THE MEXICAN AMERICAN
\end{abstract}

By

Sharon Maureen Carranza

The purpose of this study is to compile a multi-media bibliography of elementary and intermediate grade level materials in English, in English or Spanish, and in English and Spanish on the Mexican American. The bibliography is arranged by type of media under two general headings: Print and Nonprint. The Print section includes categories ranging from Biographies and Coloring Books to Reference Books and Textbooks; the Nonprint comprises categories from Audio Tapes and calendars to Recordings and slides. There are nine categories under each of the two major headings. Within each category arrangement is by author or title. Further, entries are annotated; each is a brief characterization or description of content. In sum, entries in the bibliography are constructed to facilitate the selection of materials based on standard bibliographic description, special features, and content. It should be noted that materials which were not explicitly directed toward or easily adapted to primary through eighth grades fell 
outside of the scope of this study.

The study is supplemented by a List of Abbreviations. Directory of Sources, Bibliography of References, and Author and Title Indices.

It is hoped that this bibliography will serve as a timely reference tool for use by 1) researchers, 2) school and public librarians, 3) media specialists, 4) teachers, 5) bilingual-bicultural specialists, and 6) those engaged in the training of teachers. 
This research paper was completed in partial fulfillment of the requirements for an advarced degree in the Department of Librarianship of San José State University. Short quotations may be taken from this research paper if the source is acknowledged.

This research paper will be deposited in the collection of the Department of Iibrarianship and will be available to borrowers under the rules of the Department.

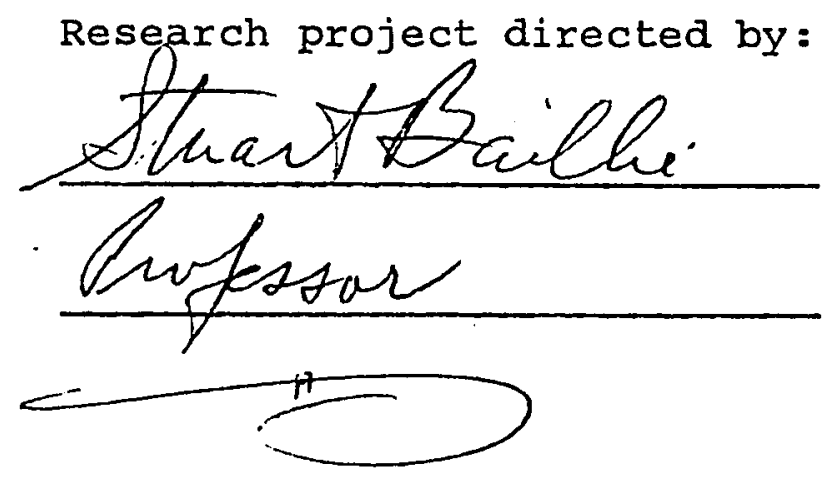




\section{ACKNOWLEDGMENTS}

The author wishes to express her gratitude to Dr. Stuart Baillie, who supervised this study, for his guidance and support. The author also thanks Dr. Shirley Hopkinson, Librarianship Department; and Mr. Hector Cordova, Chairman, Mexican American Graduate Studies Department-both of San José State University; and Mr. Gilbert Solano, Chief, Operation SHARE, Santa clara County Office of Education for their assistance. Finally, the author is indebted to her husband, Dr. Elihu Carranza, for his unstinting inspiration to excellence through countless questions, criticisms, discussions, and conversations--all kindly, patiently, and freely given, and most gratefully received. His understanding, support, and encouragement are treasured indesd. 
TABLE OF CONTENTS

CHAPTER

Page

I.

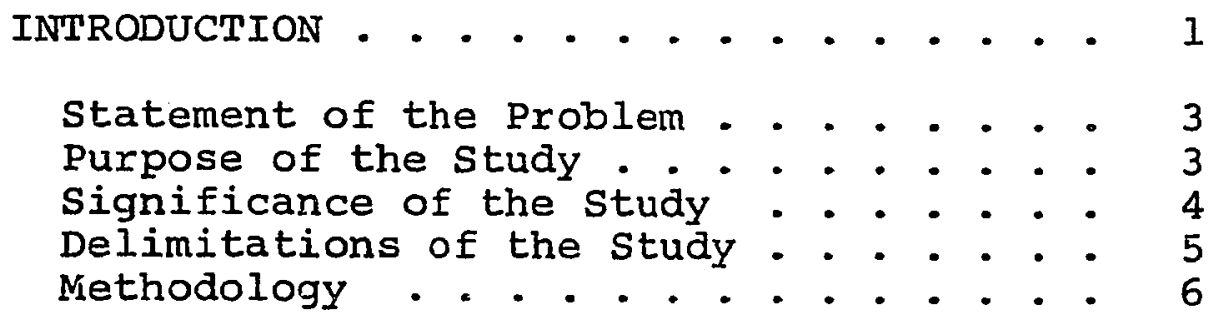

II. THE BIBLIOGRAPHY . . . . • . . . . . . 9

PRINT •. . . . . . . . . . . . . 11

Biographies . . . . . . . . . 12

Coloring Books . . . . . . . . . 15

Fiction .............. 16

Non-Fiction . . . . . . . . . . 32

Pamphlets . . . . . . . . . . 38

Picture Books . . . . . . . . 38

Poetry .. . . . . . . . . . . 40

Reference Books . . . . . . . . 41

Textbooks . . . . . . . . . . 41

NONPRINT . . . . . . . . . . . . . 44

Audio Tapes . . . . . . . . . . 45

Calendars . . . . . . . . . . . 46

Film Loops . . . . . . . . . . . 46

Filmstrips . . . . . . . . . . . . 47

Kits . . . . . . . . . . . . 54

Motion Pictures ........ . . 55

Pictures, Posters, and Study Prints - 63

Recordings... . . . . . . . . 65

Slides.. . . . . . . . . . . 65

LIST OF ABBREVIATIONS . . . . . . . . . 66

DIRECTORY OF SOURCES . . . . . . . . . . . 67

BIBLIOGRAPHY OF REEERENCES . . . . . . . . . . 75

APPENDIX . . . . . . . . . . . . . . . . . 81 


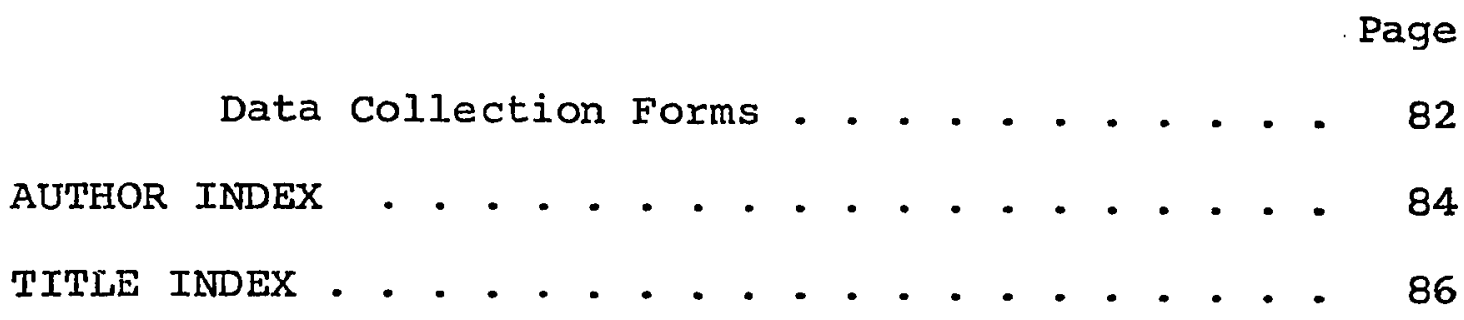


CHAPTER I

INTRODUCTION

In recent years educators have become aware of the existing need to include in our school curriculums a more comprehensive presentation of our country's rich ethnic heritage. Moreover, recent guidelines to california Education Code, Article 3.3 (Teacher Preparation). Sections 13345-13349 stipulate procedures for school staff preparation in the history, culture, and current problems of racial and ethnic minorities. I These guidelines interpret requirements concerning the in-service preparation of teachers and other professional school service personnel in schools serving substantive numbers of minority-group children. Further, they assume a shared responsibility and a cooperative effort on the part of teachers, administrators, and educators

". . to give Lour 7 students . . an understanding and appreciation of the racial, ethnic, and cultural diversity of california and the United States, so as to reinforce each student's sense of identity, dignity.

${ }^{1}$ California state Department of Education, Guidelines: School and staff Preparation in History, culture, and Current Problems of Racial and Ethnic Minorities (Sacramento: Bureau of Intergroup Relations, 1973).

$$
{ }^{2} \text { Ibid., p. iii. }
$$


As such, teachers, library-media specialists, bilingual-bicultural specialists and other professional school staff must competently communicate an understanding and appreciation of the history, culture, and current problems of Mexican Americans and other ethnic groups. In short, it is necessary that teachers and librarians relate effectively to both subject matter and to the different groups of children who make up the student body of target schools.

The wealth of recent publications of books and production of nonprint materials on Mexican Americans and other racial and ethnic minorities has created a special need for the systematic organization and presentation of these resources to more adequately meet current educational needs and practices of various professionals in the field. Library-media specialists must rely upon various book selection aids which heretofore have given scant coverage to Mexican Americans as a subject area. As for teachers, it is essential that they have a working knowledge of resources available to them when planning curriculum and preparing learning units. The bilingual-bicultural specialist clearly has special need for the organization of materials on the Mexican American. And finally, a systematic presentation of resources would serve the needs of not only those engaged in the in-service training of 
teachers, but also those engaged in the preparation of future educators.

Statement of the Problem

This study addresses the problem of bringing together in bibliographic form certain current needs as mentioned above and available print and nonprint resources that are practically useful for school and public librarians, and those educators who have realized the value of providing our children with a variety of materials about the Mexican American and his culture. Such a synthesis of needs and materials crystallized in a bibliography has added benefits if its organization facilitates the selection of materials for a comprehensive learning experience for the child using the full range of media.

\section{Purpose of the study}

The purpose of this study is to compile an annotated, multi-media bibliography of elementary and intermediate grade level materials in English, in English or Spanish, and in English and Spanish--the latter being bilingual materials, i.e., with Spanish and English parallel text--on the Mexican American. It is hoped that this bibliography will serve as a timely reference tool for use by 1) researchers, 2) school and public librarians, 3) media specialists, 4) teachers, 5) bilingual-bicultural 
specialists, and 6) those engaged in the training of teachers.

Significance of the study

The following features of the bibliography's arrangement contribute to its usefulness. It is arranged by type of media under two headings--print and nonprint-thus allowing a balanced presentation covering the full range of media (visual, oral, and written). Entries are annotated in order to facilitate selection. In addition, this study is supplemented by a List of Abbreviations, Directory of Sources, Bibliography of References, and Author and Title Indices. The data collection forms which were developed for the study are included in an appendix.

A review of the literature revealed no studies directly related to the problem under investigation. The following titles were examined in the literature search:

\author{
BIBLIOGRAPHIC INDEX \\ BOOK REVIEW DIGEST \\ BOOK REVIEW INDEX \\ CHILD DEVELOPMENT ABSTRACTS AND BIBLIOGRAPHY \\ DISSERTATION ABSTRACTS \\ EDUCATION INDEX
}

INFORMATION SCIENCE ABSTRACTS

LIBRARY AND INFORMATION SCIENCE ABSTRACTS 


\section{LIBRARY LITERATURE}

MASTERS ABSTRACTS

WORID BIBLIOGRAPHY OF BIBLIOGRAPHIES

\section{Delimitatiu.2s of the study}

The paucity of materials on the Mexican American at the elementary and intermediate grade levels in former years necessitated turning to materials on Mexico to fill the gap. This situation has been remedied with the increased publication and production of materials on the Mexican American in recent years. This study, therefore, concentrates exclusively on the Mexican American as a subject area. Books and audio visual media on Mexico and Mexicans are therefore not included.

Materials in English, in English or Spanish, and in English and Spanish (but not Spanish only) are included. This allows for the selection of bilingual materials for and by both those who are fluent in Spanish and those who are not. It is assumed that all children will profit by a greater understanding and appreciation of the rich cultural and ethnic diversity which is woven into the fabric of American life. In sum, those materials in the Spanish language only fall beyond the purpose and scope of this study.

Further, only those materials which are explicitly directed toward or those materials which are easily adapted 
to the elementary and intermediate grade levels (primary through eighth grade) are included. High school and college grade level materials fall outside the scope of the study.

Children's literature about Mexican Americans and the production of most nonbook media (with the exception of $16 \mathrm{~mm}$ films) have increased dramatically in recent years. Therefore, it will be found that a great many entries are of recent copyright date. This is not by design, since the bibliographic entries are nat delimited by copyright date.

Methodology

The bibliographical units themselves rather than secondary sources were sought out. The standard selection aids, such as SUBJECT GUIDE TO CHILDREN'S BOOKS IN PRINT; THE BEST IN CHILDREN'S BOOKS, Sutherland, ed.; Wilson's CHILDREN'S CATALOG; and others in the fields of children's. literature and audio visual media were consulted. Publisher's and producer's catalogs were also consulted for the most up-to-date sources of information. Current and back issues of HORN BOOK, VIRGINIA KIRKUS, SCHOOL LIBRARY JOURNAL, BOOKLIST, CHILDREN'S BOOK CENTER BULLETIN, and other periodicals in the field were also examined for lists and reviews. Further sources of data were provided by an ERIC search. In addition, the holdings of 
the San José Public Library, Main Branch, the Latin American Library, Oakland, the childrens collection in the San José Staice University Library (which received a federal grant to expand its collection in the bilingualbicultural area last year) and other public and school libraries in the San Francisco Bay Area which have collected in the area under investigation were researched. Two vendor exhibits were attended: the Elementary Media Fair held at the Santa clara county Fairgrounds on Octobex 24, 1974, and the Bilingual-Bicultural Media Fair held at the Santa Clara County Office of Education on February 20, 1975.

The bibliography is organized under two major headings: print and nonprint. The categories under each are:

\section{Print}

Biographies

Coloring Books

Fiction

Non-Fiction

Pamphlets

Picture Books

Poetry

Reference Books

Textbooks
Nonprint

Audio Tapes

Calendars

Film Loops

Filmstrips

Kits

Motion Pictures

Pictures, Posters, and Study Prints

Recordings

Slides 
Further arrangement is by author or title within each category. As previously noted, entries are annotated. Each annotation is either a brief characterization or description of content. 
CHAPTER II

THE BIBIIOGRAPHY

\section{organization}

Each entry of this bibliography is divided into three major areas. The first conforms to common bibliographic practice of main entry under author (or title) followed by illusträtor, place of publication, publisher (or producer, omitting place) and copyright date. The second area documents features which may assist the librarian or teacher in selecting materials. This area includes, where applicable: number (single, set of, frames); media option; size; sound statement; color statement; running time (in minutes, hours, rpm); grade level; language; price; pages; volumes; illustration statement; and binding statement. Entries without a language designation denote that the material is available in English only. The third area for each entry gives a concise description of content. The availability of catalog carüs for non-print entries, teacher's guides, maps, bibliography, and index features are also mentioned in the annotation where applicable. Some materials were not available for review and annotation; they are designated with an asterisk. 
In sum, entries in the bibliography are constructed so as to facilitate the selection of materials based on standard bibliographic description, special seatures, and content. A List of Abbreviations used follows the bibliography. 
PRINT 
Biographies

Axford, Roger $W$. SPANISH-SPEAKING HEROES: Midland, Michigan: Pendell Publishing Co.. 1973.

85p. $\$ 3.95$

A collective biography of twenty-three noted Spanishspeaking persons. Athletes, educators, businessmen, politicians, government employees, a sirger, actor, labor leader, and musician are represented. Describes their struggles, sacrifices, educational background, courage and accomplishments.

Bernard, Jacqueline. VOICES FROM THE SOUTHWEST. NeW York: Scholastic Book Services, 1972.

128p. illus. with photographs. grades 5-8. $\$ 1.65$. paper.

Each of the three life stories in this collective biography -- that of Father Antonio José Martinez, Elfego Baca, and Reies Tijerena -- are not only told from the point of view of the man whose story it is, but also reveal the long-buried history of the Southwest from which they came.

Diaz, Paul, with Kenneth G. Richards and Michael Reuben. UP FROM EL PASO. Chicago: Children's Press, 1970.

63p. illus. with photographs. grades 5-8.

A Mexican American tells of his life and of his career as a policeman and building inspector. Information about building inspectors as a career is given in four pages following the autobiography.

Franchere, Ruth. CESAR CHAVEZ. Illus. by Earl Thollander. New York: Thomas Y. Crowell Co.. 1970.

42p. illus. grades $3-5 . \$ 3.75$.

The plight of the Chavez family when they had to give up their farm during the depression and turn to migrant labor, learning the bitter facts about low pay, poor housing, and inadequate schooling is simply told in this short portrait of Cesar Chavez. These humble beginnings, his present work with the National Farm Workers Association, and his continued belief in nonviolence are described by a sympathetic author in a matter-of-fact style. 
Franco, John M. HISPANO AMERICAN CONTRIBUTORS TO AMERICAN IIFE. Westchester, Illinois: Benefic Press, n.d.

illus. grades $4-8$. $\$ 3.45$.

A collective biography of twenty-one successful Hispano Americans, primarily of Mexican, Cuban or Puerto Rican origin. Designed both to inspire and develop an appreciation for the contributions of Hispano Americans to life in the United States. Each biography begins with a life-line followed by textual matter at three progressive reading levels. A section for evaluation with questions follows each biography. A California state adopted text.

Galarza, Ernesto. BARRIO BOY. Notre Dame, Inciiana: University of Notre Dame Press, 1971.

275p. grades 7 and up. $\$ 7.95$ (paper., \$3.95).

The autobiography of this noted Mexican American author moves from an honest and unaffected telling of his early childhood in Mexico during the turmoil and tensions of the Revolution through the eventual settling of his family in Sacramento, California where he spent his youth. Providing significant insights into the process of acculturation, it is written in a style which conveys a sense of understanding and dignity which transcends the memory.

*Gutmar, Bill. JIM PLUNKETT. New York: Grosset and Dunlap, 1973.

illus. with photographs. $\$ 1.50$ paper.

Jackson, Robert B. SUPERMEX; THE LEE TREVINO STORY. New York: Henry Z. Walck, 1973.

72p. illus. with photographs. grades 5-8. $\$ 4.95$.

A biography of the famous Mexican American golfer which concentrates on his professional career. Trevino's irrepressible and senerous nersonality is manifest in the telling of his story.

*Not available for annotation. 
Lopez, Arthur, with Kenneth G. Richards. EL RANCHO DE MUCHACHOS. Chicago: Children's Press, 1970.

64p. illus. with photographs. grades 5-8. $\$ 2.25$.

The director of a ranch for delinquent boys, Natividad Boys Ranch, near Salinas, California, discusses his life and work in this autobiography. Information about social work as a career is included in the last four pages of the book:

Molnar, Joe. GRACIELA; A MEXICAN AMERICAN CHILD TELLS HER STORY. New York: Franklin Watts, 1972.

42p. illus. with photographs. grades 4-6. $\$ 4.95$.

In a text based on taped interviews 12-year-old Graciela talks of her home life in Texas with her parents and nine brothers and sisters; of the family's annual summer trip to Michigan to work in the fields; of their efforts to better themselves; and of the prejudice they sometimes encounter.

Nava, Julian, ed. MEXICAN AMERICAN PROFILES / PERFILES MEXICANO AMERICANOS. Walnut Creek, California: Aardvark Media, 1974.

116p. illus. with photographs. grades 7-8. Engl. or span. ed. avail. $\$ 4.67$. paper.

Short biographies of twenty-six Mexican American men and women are presented in this textbook which emphasizes how each individual has made an impact upon our society, and the life of the Mexican American in it. Various occupations, professions, life styles, economic backgrounds, and political viewpoints are represented. A description of how to use the book is offered, including how personal interests may affect its use, the use of the book as a basic source for study or as a supplement, and suggested activities. Includes a bibliography and index.

Newton, Clark. EAMOUS MEXICAN AMERICANS. New York: Dodd, Mead and Co., 1972.

187p. illus. with photographs. grades 7 and up. $\$ 3.95$.

A collective biography of twenty Mexican Americans from various fields of work who have attained success and acclaim for their accomplishments. Style is informal and enthusiastic. A list of source materials and an index are appended. Foreward by Dr. Uvaldo H. Palomares. 
Terzian, James P., and Kathryn Cramer. MIGHTY HARD ROAD; THE STORY OF CESAR CHAVEZ. Garden City: Doubleday, 1970.

136p. illus. with b\&w photographs. grades 6-8. $\$ 3.95$ (pi ser.. \$1.75).

A well-balanced, absorbing biography of Cesar Chavez treating also, as it were, necessarily, the cycle of poverty that is the migrant farm worker's life, the nationwide grape boycott, and the organization of workers in the California agricultural industry.

White, Florence $M$. CESAR CHAVEZ; MAN OF COURAGE. Illus. by Victor Mays. Champaign, Illinois: Garrard Publishing Co., 1973.

96p. illus. + photos. grades $3-6 . \$ 3.28$.

The story of a nonviolent man, Cesar Chavez, who suffered the same injustices and poverty as the workers he led is traced from his childhood in Arizona through his recent achievements. Index appended.

\section{Coloring Books}

Lockhart, Iinda $\mathrm{Z} .$, and Adele stinson. A ES PARA AMIGO / A IS FOR AMIGo. Illus. by John Iittleboy. Palo Alto, California: Dos Voces Press, 1974 .

48p. illus. grades K-4. bilingual. \$2.25. paper. See entry under Poetry for annotation.

Ludwig, Ed, James Santibañez, and Angie Rocha. A MEXICAN AMERICAN COLORING BOOK. Illus. by Vincent P. Rascon. Los Gatos, California: Polaris Press, 1973.

37p. illus. grades pre-school - 6 . bilingual. $\$ 1.95$. paper.

Each coloring page in this book is complimented by a page of bilingual text appearing opposite. There are seventeen such pictures with text, each treating a separate topic or theme in the history of the Mexican American. The applicable grade level range (preschool - 6) is quite wide since the book can equally be viewed either as a coloring book for young children (with illustrative text), or as a book of informative, non-fiction vignettes for older children (with illustrations). 
Eiction

Adams, Ruth. FIDELIA. Illus. by Ati Forberg. New York: Lothrop, Lee and Shepard Co.. 1970.

illus. grades 1-4. \$3.95.

Fidelia, the youngest member of the ortega family. desires to play the violin in the school orchestra, but the teacher informs her that she is too small. How she makes a violin and learns to play it is the central theme of this story.

Agnew, Edith J. TREASURES FOR TOMAS. IIlus. by Brinton Turkle. New York: Friendship Press, 1964.

126p. illus. grades 4-6. \$1.75. paper.

A lively story of Spanish American children who live in colorado.

*Baylor, Byrd. CoYOTE CRY. Illus. by symeon shimin. New York: Lothrop, Lee and Shepard Co., 1972.

34p. illus. grades 2-5. $\$ 4.50$.

Beckett, Hilary. MY BROTHER, ANGEL. IIlus. by Iouis Glanzman. New York: Dodd, Mead and Co.. 1971.

119p. illus. grades 4-6. \$3.95.

Thirteen-year-old carlos has mixed feelings about taking care of his younger brother. Angel, when their mother must leave them to care for their grandmother in Texas. Some strange incidents and tense moments on Halloween night give emphasis to his identity as a Mexican American, while he also learns to esteem the trust of a younger brother.

Beiler, Edna. TRES CASAS, TRES FAMILIAS. IIIus by Ezra Jack Keats. New York: Friendship Press, 1964.

127p. illus. grades $4-6 . \$ 1.75$. paper.

Three stories of three families -- one Cuban, one Puerto Rican and one Mexican American -- during their period of settling into a new life in the United states. The third story is about Felisa and her family who are migrant workers in south Texas. Felisa loves to read, but hates school and can never catch up due to migrant travel. She dreams of the white house they lived in long ago. 
Bishop, Curtis. FAST BREAK. Philadelphia: J. B. Lippincott, 1967.

185p. grades 6-8. $\$ 3.50$.

Rene Alvares, an immigrant Mexican boy, inspires his high school team into championship basketball.

- LITTLE LEAGUE DOUBLE PLAY. Philadelphia: J. B. Lippincott, 1962 .

189p. grades $3-6 . \$ 3.50$.

A young Chicano is the hero in this lively baseball story.

Bonham, Frank. VIVA CHICANO. New York: E. P. Dutton, 1970 .

179p. grades 7 and up. $\$ 4.50$ (paper., 75\%, Dell Publishing Co.).

Gangs, drugs, street fights, an unhappy home and more -- all form the makings of the world of Keeny Duran, a juvenile delinquent on parole in an urban ghetto. The plot's resolution turns on the hero's new found inspiration in the life of Emiliano Zapata.

Buffler, Esther. RODRIGO AND ROSAIITA. Illus. by Elizabeth Rice. Austin: Steck-Vaughn, 1949.

64p. illus. grades $3-5$. $\$ 2.95$.

The Castillos have a close family life. When the father becomes too ill to continue working and support his family, his children work to buy him artist materials so that he may realize his desire to paint while recovering. Then one day an art dealer from New York happens upon his work, bringing the story to a happy close.

Bulla, Clyde R. BENITO. Illus, by Valenti Argelo. New York: Thomas Y. Crowell, 1961.

84p. illus. grades 3-5. \$3.50.

Benito, an orphan boy, suffers ill treatment in tha home of an uncle who has taken him in, but eventually he finds fulfillment and independence when a friendship develops between himself and a local artist. 
Clark, Ann Nolan. PACO'S MIRACLE. Illus. by Agnes Tait. New York: Farrar, Straus and Giroux, 1962.

159p. illus. grades 4-6. \$3.50.

When the old One falls ill, Paco leaves his lean-to in the mountains of New Mexico and strives to learn the ways of a spanish family in a nearby village with whom he goes to live. He almost forgets the mountains until one night the animals call him. A gentle story in which the theme of kindness to all things predominates.

New York: SANTO FOR PASQUALITA. Illus. by Mary villarejo. 96p. illus. grades $3-5$. $\$ 2.75$.

An orphan girl is adopted by an aged couple. Since the man is a santero, one who carves figures of patron saints, the story turns on discovering the likeness of her patron saint. St. Pasqual, so that his figure may be carved for hex. The Mexican American is unnecessarily characterized as being somewhat primitive and superstituous.

Colman, Hila. CHICANO GIRL. iNew York: William Morrow, 1973.

191p. grades 7 and up. \$4.95.

After some bitter experiences in the Anglo world, a young Chicana begins the search for her identity and heritage. An apparent misnomer appears in the title since the ' $O$ ' ending in "Chicano" designates masculine gender.

Cox, William R. CHICANO CRUZ. New York: Bantam Books, 1972 .

224p. grades 6-8. 75\%. paper.

Story of a young Mexican American boy who works his way into the major leagues of basebuil.

Dunne, Mary C. REACH OUT, RICARDO. New York: AbelardSchuman, 1971.

157p. grades 5-8. $\$ 4.95$.

A fifteen-year-old Chicano finds that his life becomes complicated when his father joins a farm workers strike. 
Eberle, Irmengarde. THE VERY GOOD NEIGHBORS. Illus. by Flora Nash DeMuth. Philadelphia: J. B. Lippincott, 1945 .

96p. illus. grades 4-6.

An interesting story line is marked by warm family relations, bleak conditions of poverty, and ultimately, some friendly (but somewhat condescending) neighbors.

Ets, Marie Hall. BAD BOY, GOOD BOY. Illus. by the author. New York: Thomas Y. Crowell, 1967.

50p. illus. grades $1-3 . \$ 3.95$.

With five children sleeping in one room, his parents quarreling, and the neighbors and shopkeepers always scolding hiil, Roberto is a child greatly in need of attention and care. The story is told with too much candor and simplicity to be grim, but the circumstances of this child's world are nevertheless portrayed without disguise.

Eyre, Katherine W. STAR IN THE WILLOWS. Illus. by Gertrude Howe. New York: Oxford University Press, 1946 .

174p. illus. grades $5-7$.

Ten-year-old Nita demonstrates her loyalty when she helps save the ranch on which she lives with her aunt and uncle, who have come as workers from a small Mexican town.

Felt, Sue. ROSA-TOO-IITTLE. Illus. by the author. Garden City, New York: Doubleday, 1950.

25p. illus. grades $\mathrm{k}-2$. $\$ 3.95$.

Little Rosa practices secretly all summer long so that she can sign for a library card. Portrays the joy and pride in a wish come true. 
Forsee, Aylesa. TOO MUCH DOG. Illus. by Harper Johnson. Philadelphia: J. B. Lippincott, 1957.

192p. illus. grades 4-6.

A tale of the love between Fidel, a young Mexican American boy living with his family in New Mexico, and his grandfather with whom he journeys to Colorado to pick fruit. Backdrop of migrant camps, dogs, a bandit, and a New Mexican Christmas.

Foster, Ed. TEJANOS. La Raza Series. Illus. by Bill

Negron. New York: Hill and Wang, 1970.

48p. illus. grades 5-8. paper.

Eleven-year-old Enrique watches his father die defending the Alamo, knowing that his uncle is fighting with the enemy. Introduction by Richard G. Santos.

Freeman, Dorothy R., THE FRIDAY SURPRISE. Illus. by Mary Murphy. Whittier, California: Elk Grove Press, 1968.

42p. illus. grades $\mathrm{K}-3$.

Every Friday Mario brings home a gift from his art class to members of his family. On the last Friday there is no art class, so no surprise for Mario's father. Instead, he receives the best gift of all.

A HOME FOR MEMO. Illus. by Bernard Garbutt. Whittier, California: Elk Grove Press, 1968.

54p. illus. grades 4-6.

A migrant family from Mexico comes to work on a lemon ranch in ventura county during picking season. As time goes by they decide to stay and make a new home at this California ranch, so Memo must adjust to this new place.

Galbraith, Clare K. VICTOR. Illus, by Bill Commerford. Boston: Little, Brown and Co., 1971.

48p. illus. grades $2-4$. $\$ 3.50$.

Division threatens Victor's life when the Englishspeaking Anglo world of school never seems to come together with the Spanish-speaking world of his Mexican American home. How he is able to reconcile the differences is the basis of this story. Includes a glossary of Spanish words and phrases. 
Garthwaite, Marion. MARIO; A MEXICAN BOY:'S ADVENTURE. Illus. by Ronni Solbert. Garden City, New York: Doubleday, 1960.

167p. illus. grades $4-6$. $\$ 2.95$.

Eleven year old Mario, who lived in Baja California with his grandmother, became an unwitting wetback when he fell into the hands of an unscrupulous agent seeking cotton pickers for the Imperial Valley ranches. Terrified and bewildered, yet sustained by his innate dignity and pride, he is saved by friendly people who deliver him to his family again.

Gates, Doris. BLUE WILLOW. Illus. by Paul Lantz. New York: Viking Press, 1940.

172p. illus. grades 5-8. $\$ 3.50$ (paper., 75\%).

The development of friendship between a Mexican American family and another migrant family, as it took place in California in the mid-1930's, is described realistically in this classic and loved story. Believable characters and a well paced plot combine with an unsentimental but sympathetic treatment of a tragic subject. As one of the earliest children's books to treat the subject of migrant workers, it is a poignant tale of the difficult and disorganized life led by all migrant workers--Mexican American or white. Though a bit dated, the problems of such families remain essentially the same, and so do children's reactions to them.

Gee, Maurine H. CHICANO, Airigo. Illus, by Ted Lewin. New York: William Morrow, 1972.

96p. illus. grades $4-6$. $\$ 3.95$.

The unswerving aim of eight-year-old Kiki is to become a cub scout. In his enthusiasm he adopts a friend and reluctant hero, Marc conley, whom he involves in endless complications as his protégé. 
Greene, Carla. MANUEL, YOUNG MEXICAN AMERICAN. Illus. by Haris Petie. New York: Lantern Press, 1969.

47 p. illus. grades $3-5$. $\$ 3.50$.

Jimmy learns how people from various ethnic backgrounds can be American and still observe the customs and holidays of their homeland. Stresses informed intercultural relations in the developing friendship between Jimmy and Manuel.

Halladay, Anne M. NEW FRIENDS FOR PEPE. IIlus. by Janet Smalley. St. Louis: Bethany Press, 1959.

illus. grades $1-2$. $\$ 1.00$.

An unassuming little story in which the migrant child is shown as being much like other children -- that is, involved in day-to-day concerns rather than great social issues.

* SECRETS AT WHITE OWL. Illus. by Betsy Warren. Austin: Steck-Vaughn Co., 1967.

87p. illus. grades $3-5$. $\$ 2.95$.

Hampton, Doris. JUST FOR MANUEL. Illus. by Carol Rogers. Austin: Steck-Vaughn Co., 1971.

$32 \mathrm{p}$. illus. grades $\mathrm{K}-3$. $\$ 3.25$.

Since Manuel lives in a crowded apartment, it is not easy for him to find a special place of his own. But his understanding mother encourages him to keep looking and lets him keep the place he finally finds.

Hitte, Kathryn, and William D. Hayes. MEXICALI SOUP. Illus. by Anne Rockwell. New York: Parents' Magazine Press, 1970.

36p. illus. grades $1-3 . \$ 3.95$.

The delicious homemade soup that mama's family loves cannot escape the pressures of assimilation her husband and children feel. They ask her to omit so many ingredients that finally none remain. 
Hood, Flora. ONE LUMINARIA FOR ANTONIO. Illus. by Ann Kirn. New York: G. P. Putnam, 1966.

46p. illus. grades $\mathrm{K}-3 . \quad \$ 2.97$.

Antonio prepares for Christmas by making a luminaria, a lantern made of a candle set in sand inside a paper bag.

Krumgold, Joseph. AND NOW MIGUEL. Illus. by Jean Charlot. New York: Thomas Y. Crowell, 1953.

245p. illus. grades 5-8. \$4.50.

This Newberry Award winning book tells the story of Miguel and his great longing to accompany the men of his family and sheep to the summer pasture in the Sangre de Cristo Mountains of New Mexico. He succeeds not only in realizing his hope, but in gaining recognition as an individual.

Laklan, Carli. MIGRANT GIRL. New York: McGraw-Hill, 1970.

144p. grades 5-8. $\$ 4.95$.

Dacey, the daughter of a migrant family, meets Juan, a young Mexican American who is trying to organize a union, using Cesar Chavez as a model. Through their friendship she gains hope for the future. Eastcoast setting.

Lampman, Evelyn S. THE BANDIT OF MOK HILI. Illus. by Mai'vin Friedman. Garden City, New York: Doubleday, 1969.

254p. illus. grades 5-8. \$3.95.

An adventurous, fast-paced story in which a young boy leaves San Francisco to travel to the gold fields where he intends to join the band of the "avenger", Joaquin Murrieta.

- GO UP THE ROAD. Illus. by Charles Robinson. New York: Atheneum, 1972 .

187p. illus. grades 5-8. $\$ 5.50$.

Once again twelve-year-old Yolanda had to leave school before the end of the term, thus failing to pass into fifth grade. Yolanda's story and how she achieved her goal of reaching fifth grade demonstrates the 
plight of the migrant worker as well. By the close of the book she and her family glimpse a more stable way of life and the possibility of sharing it.

Lexau, Joan M. MARIA. Illus. by Ernest Crichlow. New York: Dial Press, 1964.

32p. illus. grades $3-4$. $\$ 3.50$.

The hierloom doll which had belonged to Maria's grandmother was a gift of such great value that Maria was not permitted to play with it. But her parents find an alternative.

Madison, Winifred. MARIA LUISA. Philadelphia: J.B. Lippincott, 1971.

187p. grades 5-8. $\$ 4.43$ (paper., $\$ 1.95)$.

Since her mother is $i 11$ in the hospital twelve-yearold Maria Luisa and Juan, her six-year-old brother, travel from San Luis, Arizona to San Francisco where she is to live with relatives. She is warmly received by her aunt, but meets with a barrage of small defeats socially, and with the language in school. A sympathetic teacher and a young Danish boy, Peter, come into her life and give her friendship, comfort, and courage.

Martin, Patricia M. TRINA'S BOXCAR. Illus. by Robert L. Jefferson. Nashville: Abingdon, 1967.

112p. illus. grades 4-6. $\$ 3.25$ (paper., 60\%, Scholastic Book Services).

Trina and her railroading family live in a boxcar in Wyoming. A new town brings a friend for Trina, and the opportunity to learn to speak English.

Means, Florence. TERESITA OF THE VALLEY. Illus. by Nicholas Panesis. Boston: Houghton Mifflin, 1943.

166p. illus. grades 7-8.

Story of a girl who finds occasions for pride in both sides of her ancestry, and establishes a new home for her family in Denver. 
Molarsky, Osmond. RIGHT THUMB, LEFT THUMB. Illus . by John E. Johnson. Menlo Park, California: AddisonWesley, 1969.

illus. grades $\mathrm{K}-3 . \quad \$ 4.60$.

The day victor goes to the store all by himself is indeed one of his most successful days. The use of string tied to his thumb reminds him of right and left.

Nava, Julian, series editor. Bilingual stories for Today Series.

The following six titles are part of a sequential, developmental series of eight bilingual-bicultural and ESI supplementary reading books. The stories are based on the life experiences of children with whom the authors have worked, and deal with problems and controversial issues as well as happy experiences. They are designed to enhance respect and understanding of the Mexican American cultural heritage. Differences between Mexican Americans and Anglos are seen as enriching life. The other two titles in the series are A TRADITIONAL VOICE IN THE BARRIO (NOn-Fiction), and MEXICAN AMERICAN PROFILES (Biography).

CUSTOMS ACROSS THE BORDER / COSTUMBRES DEL OTRO IADO DE LA FRONTERA. Walnut Creek, California: Aardvark Media, 1974 .

46p. illus. + photos. Engl. or span. ed. avail. $\$ 2.60$. paper.

Four stories. See series annotation above.

HAPPY DAYS / DIAS FELICES. Walnut Creek, California: Aardvark Media, 1974.

46p. illus. with photographs. Engl. or Span. ed. avail. $\$ 2.60$. paper.

Four stories. See series annotation above. - MY FAMIIY / MI FAMILIA. Walnut Creek, California: Aardvark Media, 1974.

46p. illus. + photos. Engl. or Span. ed. avail. $\$ 2.60$. paper.

Five stories. See series annotation above. 
MY FRIENDS / MIS AMIGOS Walnut Creek,

California: Aardvark Media, 1974.

46p. illus. Engl. or Span. ed. avail. \$2.60. paper.

Seven stories. See series annotation above.

- MYSELF / YO. Walnut creek, California:

Aardvark Media, 1974 .

44p. ¡llus. Engl. or Span. ed. avail. \$2.60. paper.

Twelve stories. See series annotation above.

Creek, California: Aardvark Media, 1974.

46p. illus. + photos. Engl. or span. ed. avail. $\$ 2.60$. paper.

Four stories. See series annotation above.

o'Dell, scott. CHILD OF FIRE. Boston: Houghton Mifflin, 1974.

213p. grades 7 and up. $\$ 5.95$.

A parole officer relates his efforts to keep the violence and heroics of two young chicanos under control in an environment which prompts repeated risk-taking.

Ormsby, Virginia H. TWENTY-ONE CHILDREN. Philadelphia:

J. B. Lippincott, 1957 .

illus.

Emalina can't speak English, but the class finds it rewarding to teach her while she teaches them Spanish.

- TWENTY-ONE CHILDREN PLUS TEN. IIIUS. by the author. Philadelphia: J. B. Lippincott, 1971.

32p. illus. grades $\mathrm{K}-3$. $\$ 3.95$.

When ten new children from "the other side of town" join a second grade class, the original cl is group reacts negatively. But when Rosita runs away they all work together to find her. 
Politi, Leo. JUANITA. Illus. by the author. New York: Scribner, 1948.

30p. illus. grades $1-3 . \$ 5.95$.

A story of Juanita's fourth birthday party, the presents she receives and the traditional Easter blessing of the animals on olvera street in Los Angeles. Includes music. It should be cautioned that the author has a tendency to equate the customs of Mexican Americans with the celebration of festivals in this book and in PEDRO, THE ANGEL OF OLVERA STREET. $\mathrm{His}$ illustrations are also subject to criticism.

THE NICEST GIFT. Illus. by the author. New York: Scribner, 1973.

26p. illus. grades $\mathrm{K}-3$.

A little boy living in the barrio of East Los Angeles is desolate when Christmas Day arrives and his lost dog still has not been found. The theme of a lost pet and the clever resolution make this a year round story. Unfortunately, the author's view that "The Barrio is quaint and picturesque," and his illustrations which tend to stereotype serve to mar this book.

PEDRO, THE ANGEL OF OLVERA STREET. IIlus. bY

the author. New York: Scribner, 1946.

28p. illus. grades 1-3. Engl. or Span. ed. avail. $\$ 5.95$.

Because Pedro sings so beautifully. he is chosen to lead Ia Posada at Christmas time. The setting is olvera Street, Los Angeles. Words and music for two carols are included. Again, as noted above, picturesque holidays and festivals, even if accurately depicted, do not constitute an entire culture.

SONG OF THE SWALIOWS. Illus. by the author. New York: Scribner, 1949.

30p. illus. grades $1-3 . \$ 3.25$.

A picture story relating the legend of the swallows who return each year to the Mission of San Juan Capistrano. Juan's warm friendship with old Julian, the bell-ringer of the Mission, his patience rewarded on the scheduled day, and the colorful illustrations all make a happy setting for this story. 
Robinson, Benelle H. CITIZEN PABLO. IIlus. by Jean Macdonald Porter. New York: John Day, 1959.

128p. illus. grades 4-6. \$3.69.

Twelve-year-old Pablo and his family leave Mexico to escape starvation. In their search for a better home in Texas and California they meet with many disappointments and frustrations which are poignantly pictured as part of their life as migrant workers. The author does not shy away from some unpleasant. unadorned experiences and conditions of migrant life not always found in children's books.

* Rydberg, Ernie. BRIGHT SUMMER. Illus. by Vera Neville. New York: Longmans, Green, 1953.

131p. illus. grades $4-6$.

Schaefer, Jack. OLD RAMON. Illus. by Harold West. Palo Alto, California: Houghton Mifflin, 1960.

102p. illus. grades 5-8. \$2.50.

When the shepherd, Ramon, takes the sheep to high country for grazing, his dog and the son of his patron join him and share his adventures. A sympathetically narrated story of a simple life.

Schweitzer, Byrd Baylor. AMIGo. Illus. by Garth Williams. New York: Macmillan, 1963.

41p. illus. grades $2-4 . \quad \$ 3.95$.

A lyrical, narrative, verse story about Francisco, a sensitive boy who finds a prairie dog to be his friend. Beautiful illustrations.

Summers, James I. YOU CAN'T MAKE IT BY BUS. Philadelphia: Westminister Press, 1969.

174p. grades 7 and up. $\$ 3.95$.

A southern california high school boy finds his loyalties divided between the values of his father, a Mexican immigrant, and those of the Brown Berets, a group of young Mexican Americans. Other elements of the plot include the theme of returning to Mexico as a way of solving problems, a student strike, and a romance between the story's hero and his Jewish girlfriend. 
Taylor, Florance W. A Feliṕpe Adventure story Series.

The following seven titles are stories whose main character is Felipe, a Mexican American boy whose home is in the Texas Rio Grande Valley. His family are migrant farm workers who follow the crops, and in April they leave Texas and travel to Illinois for the summer months. Felipe is a mature boy who overcomes many prejudices and hardships in striving for the good oi himself and his family.

BALI TWO: Illus. by George Overlie. Minneapolis: Lerner Publications Co., 1971.

32p. illus. grades 3-5. \$3.95.

Felipe and other boys from the labor camp run into trouble when they play baseball on a vacant lot out of bounds to them -- especially when a wild pitch sails over his head and breaks a window. See also series annotation above.

- THE CORN FESTIVAL. Illus. by George Overlie. Minneapolis: Lerner Publications Co., 1971.

32p. illus. grades $3-5 . \$ 3.95$.

When he is injured trying to save Karen from an accident, Felipe gains the acceptance of her grandmother and a hero's acclaim. See also series annotation above.

- FROM TEXAS TO ILIINOIS. Illus. by George Overlie. Minneapolis: Lerner Publications Co.. 1971.

32p. illus. grades 3-5. \$3.95.

Felipe is unhappy about leaving his home in Texas for the trip to Illinois, but after they arrive he concludes that home is where family and friends are. See also series annotation above.

- A PLANE RIDE. Illus. by George Overlie. Minneapolis: Lerner Publications Co., 1971.

32p. illus. grades 3-5. \$3.95.

Felipe and Luis tumble out of the truck and are accidentally left behind when the migrant camp leaves for Texas. A dreamed-of airplane ride returns them to their parents. See also series annotation above. 
THE SCHOOL PICNIC. Illus. by George Overlie. Minneapolis: Lerner Publications Co.. 1971.

32p. illus. grades 3-5. \$3.95.

The school picnic is held on the bluifs near a river, and during a game of I Spy, Karen is accidentally knocked down the hill. Whe: the picnic is over it is discovered that she is missing. See also series annotation above.

WHAT IS A MIGRANT? Illus. by George Overlie. Minneapolis: Lerner Publications Co., 1971.

32p. illus. grades 3-5. \$3.95.

Felipe encounters racism when a fourth grade girl he thinks is an "angel" calls nim a "filthy Mexican migrant." See also series annotation above.

WHERE'S LUIS? IIlus. by George Overlie.

Minneapolis: Lerner Publications Co., 1971.

32p. illus. grades $3-5 . \$ 3.95$.

Felipe attends the first day of summer school but he must also babysit for his little brother. He solves this by taking him to school with him in the new stroller, but by mid-morning Luis has completely disappeared. See also series annotation above.

Taylor, Theodore. THE MALDONADO MIRACLE. Garden city, New York: Doubleday, 1973.

189p. grades 6-8. \$4.50.

A young Mexican boy crosses the border illegally to join his father as a field worker in the United states. By causing what appears to be a miracle, he inadvertently triggers a wave of hysteria in a small California town.

Todd, Barbara K. JUAN PATRICIO. Illus. by Gloria Kamen. East Rutherford, New Jersey: G. P. Putnam, 1972.

42p. illus. grades $1-3 . \$ 3.69$.

A pleasant story about a child's first efforts to be independent. Excellent illustrations and simple text record young Juan Patricio's adventures as he sets out to find a summer job in santa Fe. The author uses spanish words in context without artificial translation into English. 
Tuckex, David. SOMETHING SPECIAL. Illus. by Elizabeth Dauber. New York: Grosset and Dunlap, 1970.

63p. illus. grades $\mathrm{K}-3 . \$ 1.00$

One day Pablo's father comes to his school and takes Pablo and his friend Billy to pick up "something special," Pablo's new baby brother. Underlying theme of friendship between children of different cultural backgrounds.

Van Der Veer, Judy. HOLD THE REIN FREE. Illus. by Bernard Garbutt. Los Angeles: Golden Gate Junior Books, 1966.

243p. illus. $\$ 3.79$.

When Kiki, a Mexican American boy, and his friend Amy learn that an unborn foal will be destroyed because she is not a thoroughbred, they plot to save her life.

Vasquez, Richard. CHICANO. Garden City, New York: Doubleday, 1970 .

(paper.. \$1.25, Avon Books).

A novel about four generations of family migration and struggle, beginning in 1910 in Revolutionary Mexico and following through to the barrio of east Los Angeles.

Villasenor, Edmund. MACHO: New York: Bantam Books.

256p. grades 7 and up. 95\%. paper.

Roberto, the eldest son of a poor Mexican family, goes north to the states as a migrant worker. Roberto comes of age during these years of back-breaking work. and against a background of cesar chavez's efforts to improve conditions for field workers. On returning to Mexico, he views things with a new perspective.

Waugh, Julia Nott. THE SILVER CRADLE. Austin: University of Texas Press, 1955.

grades $6-8$

An information oriented story about a family in san Antonio depicting certain customs and celebrations. 
Whitney, Phyllis A. A LONG TIME COMING New York: David Mckay, 1954.

256p. grades 6-8. $\$ 4.50$ (paper.. 50

A story which laces prejudice, violence, ocial problems, a generous helping of romance, - $r$. religious conflict.

Young, BOb. GOOD-BYE AMIGOS. New York: Juliar. wassner, 1963.

grades $6-8$

Cathy Miller, the daughter of a wealthy rancher. befriends the migrant Garcia family. Her loyalties are divided when the migrant workers strike and she is in sympathy for them.

Young, BOb and Jan. ACROSS THE TRACKS. New York: Julian Messner, 1958.

192p. grades 7 and up. $\$ 3.50$ (paper., 60\%. Washington Square Press).

A Mexican American giri is shocked to realize that she is ashamed of her background and prejudiced toward her own people whom she is accused of deserting. Tragedy brings about a change.

\section{Non-Fiction}

Ballis, George. BASTA! LA HISTORIA DE NUESTRA LUCHA / ENOUGH! THE TALE OF OUR STRUGGLE. Delano, California: Farm Worker Press, 1966.

72p. illus. with photographs. grades 7 and up. bilingual. \$2.50. paper.

This photo essay about the Delano grape strike is based on text from the Plan of Delano.

Bay Area Bilingual Education League. RAZA CULTURAL EVENTS SERIES. Berkeley: Bay Area Bilingual Education League, n.d.

llv. grades $4-8$. bilingual. $\$ 2.50$ ea.

Eleven cultural units, each dealing with seasonal events and activities, offer background information, illustrations, activities and evaluation. The titles 
are: 1) Día de los Muertos; 2) Juan Diego; 3) Las Posadas; 4) Día de los Reyes Magos; 5) La Candelaria; 6) Música de la Raza; 7) Cesar Chavez; 8) Cinco de Mayo; 9) Día de las Madres; 10) Mujeres de la Raza; and 11) Pasos Hacia la Humanidad.

Bond, Jean C. BROWN IS A BEAUTIFUL COLOR. Illus. by Barbara Zuber. New York: Franklin Watts, 1969. 39p. illus. grades $\mathrm{K}-3$.

Tells of all the wonderful things that brown is, and that are brown.

Brock, Virginia. PIÑATAS. Illus. by Anne Marie Jauss. Nashville: Abingdon Press, 1966.

112p. illus. + photos. grades 4-8. \$3.00.

The piñata is pretty, decorative, exciting and mysterious--and it is designed to be broken. The author of this book tells how the piñata began; how to use a piñata; how to make a piñata (11 different kinds); and three little stories. Includes diagrams, a glossary and pronunciation guide.

*Bustamante, Charles and Patricia. THE MEXICAN AMERICAN AND THE UNITED STATES. Mountain View, California: Patty-Lar Publications.

\section{illus. grades $7-8$.}

Center for the Study of Instruction, San Francisco, in coilaboration with Philip Johnson. A PROBE INTO MEXICAN AMERICAN EXPERIENCE / UN EXAMEN SOBRE LA EXPERIENCIA DE LOS MEXICOAMERICANOS. New York: Harcourt, Brace, Jovanovich, 1973.

311p. illus. + photos. grades 5 and up. bilingual. paper.

This excellent book which approaches the history and experience of Mexican Americans with the question, "Who am I?" should be quite appealing to the young reader across a wide range of grade levels. The writing style is informative rather than condescending, provocative rather than propagandistic. The format, type size and face, and the brown ink on off-white paper also contribute to the book's appeal. Includes a few maps, and a bibliography. 
*Degarza, Patricia. CHICANOS; THE STORY OF MEXICAN AMERICANS. New York: Julian Messner, 1973.

96p. illus. with photographs. $\$ 5.50$.

Dobrin, Arnold. THE NEW LIFE--LA VIDA NUEVA; THE MEXICAN AMERICANS TODAY. New York: Dodd, Mead and Co., 1971.

109p. illus. with photographs. grades 5-7. \$3.95.

An overview of the Chicanos: their history, problems as a minority group, and goals. The major portion of the book is devoted to interviews with individual ordinary citizens (a few--Ricardo Montalban and Cesar Chavez--are famous) who tell their feelings about prejudice, political actions, education, family solidarity, and the discriminatory treatment they have received. This use of the interview technique gives a sense of immediacy and personal involvement. The writing style is clear and direct, though the transitions from topic to topic are sometimes abrupt. Index and bibliography.

Eiseman, Alberta. MA NANA IS NOW; THE SPANISH-SPEAKING IN THE UNITED STATES. New York: Atheneum, 1973.

181p. grades 5-8. $\$ 6.25$.

A review of the history, problems, and goals of cubans, Chicanos, Puerto Ricans, and other Hispanos in the United States. Bibliography.

Fitch, Robert B. and Lynne. SOY CHICANO; I AM MEXICAN AMERICAN. Mankato, Minnesota: Creative Educational Society, 1970 .

64p. illus. with photographs. grades 5-8. $\$ 5.95$.

Thirteen-year-old Lupe, the daughter of a farm worker who lives in Earlimart, california, describes her home, family, school, and daily experiences in this inviting book.

*Galarza, Ernesto, et al. MEXICAN AMERICANS IN THE SOUTHWEST. Illus. by George Bailis. Chicago: Rand McNally, 1970.

90p. illus. with photographs. grades 7 and up. $\$ 2.50$. paper. 
Garcia, Ernest F., and George Shaftel. MEXICAN AMERICAN HERITAGE. Belmont, California: Fearon.

illus. grades 5-8. \$5.60.

Beginning with life in the Americas before Columbus, the book goes on to trace the Spanish influence through South America, Mexico, and North America. A chapter is devoted to modern Mexico, and the last chapter treats outstanding Mexican Americans, past and present. Each chapter is followed by study questions. Maps.

THE HERITAGE AND CONTRIBUTIONS OF THE HISPANIC AMERICAN. Denver: Department of Instructional Services, Denver Public Schocis, 1969.

Gives an account of the history and contributions of Spanish-speaking persons in the Southwest.

*Kallas, and Perez. PRIDE OF ATZLAN; A BILINGUAL SURVEY OF MEXICAN HISTORY. (Distributed by El Dorado

Distributors).

bilingual. $\$ 4.50$.

Martin, Patricia Miles. CHICANOS; MEXICANS IN THE UNITED STATES. Illus. by Robert Frankenberg. New York:

Parents" Mag̣azine Press, 1971.

64p. illus. grades 2-4. $\$ 3.78$.

Traces the history of Mexican migration into the U.S., describes the immigrant's way of life, and outlines their contributions to the United States. Index.

Martinez, Elizabeth, and Enriqueta L. Vasquez. VIVA LA RAZA: THE STRUGGLE OF THE MEXICAN AMERICAN PEOPLE. Garden City, New York: Doubleday, 1974 .

336p. illus. grades 7-8. \$4.95.

The plight of poverty and prejudice, the quest, and the history of Mexican Americans are given an account in this tovk, with special emphasis on prominent recent chicano leaders.

*Martinez, Rafael V. MY HOUSE IS YOUR HOUSE. New York: Friendship Press, 1964.

127p. illus. with photographs. grades 7 and up. $\$ 1.95$. paper. 
Nava, Julian, series editor. A TRADITIONAL VOICE IN THE BARRIO / UNA VOZ TRADICIONAI DEL BARRIO. Bilingual Stories for Today Series. Walnut Creek, California: Aardvark Media, 1974.

96p. illus. with photographs. Engl. or Span. ed. avail. $\$ 4.67$. paper.

Over twenty short essays. See series annotation under Fiction.

Pinchot, Jane. THE MEXICANS IN AMERICA. Minneapolis: Lerner Publications, 1973.

99p. illus. grades 5-8. \$3.95.

Gives a brief history of Mexicans in the United states-their life in the southwest before statehood, the government's acquisition of their land, and the individual contributions of Mexican Americans. Index.

Prago, Albert. STRANGERS IN THEIR OWN IANDS; A HISTORY OF MEXICAN AMERICANS. New York: Four Winds Press, $1973=$

226p. illus. with photographs. grades 7 and up. $\$ 5.95$.

A history characterized by hardship, discrimination, and exploitation is treated in this book which includes the stories of Benito Juarez, Emiliano Zapata, Pancho Villa, and more recent leaders, including cesar Chavez, who have fought against these conditions. Bibliography and Index.

steiner, stanley. IA RAZA; THE MEXICAN AMERICANS. New York: Harper and Row, 1970.

418p. illus. \$8.95 (paper.. \$1.95).

Treats incidents in the chicano movement for recognition through narratives and reports. Bibliography. 
Tebbel, John, and Ramon Ruiz. SOUTH BY SOUTHWEST; THE MEXICAN AMERICAN AND HIS HERITAGE. IIlus. by Eari Thollander. Garden City, New York: Doubleday, 1969. 122p. illus. grades 7 and up. $\$ 3.75$ (paper.. $\$ 1.45)$.

Explores the heritage of the Mexican American and the history of the Southwest. Concentrates heavily on the history of Mexico. Maps and Index. A teacher's manual is also available.

Turner, Mary, ed. WE, TOO, BELONG: AN ANTHOLOGY ABOUT MINORITIES IN AMERICA. New York: Dell, 1969.

224p. grades 7 and up. 75k. paper.

This is an anthology of plays, poems, short stories and essays about minorities in America.

Weiner, Sandra. SMALL HANDS, BIG HANDS; SEVEN PROFILES OF CHICANO MIGRANT WORKERS AND THEIR FAMILIES. NEW York: Pantheon Books, 1970.

55p. illus. with photographs. grades 4 and up. $\$ 3.95$.

These vignettes emerged from the author's taped conversations with various families over a period of several months. They range in age from eleven to seventy-three. The author-photographer is known for her unstereotyped work.

Weiss, Karel. UNDER THE MASK: AN ANTHOLOGY ABOUT PREJUDICE IN AMERICA. NeW York: Dell, 1973.

208p. grades 7 and up. \$1.25. paper.

The decline of racial pride and its later resurgence among Americans of Mexican, African, Indian, Puerto Rican, and Japanese descent is traced in selections from poems, documents, songs, periodical and newspaper articles, and books. The arrangement of the readings emphasizes the parallel experiences of minorities in the United states. 
Young, Jan. THE MIGRANT WORKERS AND CESAR CHAVEZ. NEW York: Julian Messner, 1972.

189p. illus. with photographs. grades 7-8. $\$ 4.50$.

This is the story of the long and bitter labor battle between the California farm workers and growers, and the man who led it. Bibliography and Index.

\section{Pamphlets}

MCWilliams, CareY. THE MEXICANS IN AMERICA; A STUDENTS' GUIDE TO LOCALIZED HISTORY. NeW YOrk: Teachers College Press, Columbia University, 1968.

32p. grades 7 and up. $\$ 1.50$. paper.

Gives some concept of where and at what time Mexicans settled in significant numbers in this country, something of their history as Americans, and follows that history to current times. Contains chapters on $A$ Special Minority; The Great Invasion; The Mexican Problem; and New Stirrings in the Borderlands. Bibliography.

\section{Picture Books}

Bolognese, Don. A NEW DAY. Illus. by the author. New York: Delacorte Press, 1970.

28p. illus. grades $\mathrm{K}-2$. $\$ 4.95$.

A migrant Mexican American family are the main characters in this story with a biblical theme, but a contemporary setting. Illustrated in beautiful, vibrant colors.

Ets, Marie Hall. GILBERTO AND THE WIND / GILBERTO Y EL VIENTO. Illus. by the author. New York: Viking Press, 1963.

32p. illus. grades $\mathrm{k}-2$. Engl. or Span. ed. avail. $\$ 3.00$ (paper.. 85\%).

Gilberto has a changeable, unpredictable, playful companion named Wind--not. "the Wind"--just Wind. This beautifully illustrated, delightful book has those rare qualities of wonder and imagination. See also entries for this same work under Filmstrips, Motion Pictures, and Recordings. 
Jaynes, Ruth M. MELINDA'S CHRISTMAS STOCKING. Illus. by Richard George. Glendale, California: Bowmar, 1968.

25p. illus. with photographs. grades $\mathrm{k}-2$. $\$ 3.24$ paper.

Family relationships are portrayed in this story with a Christmas theme. Adopted as a California state text in 1971.

- TELL ME, PLEASE! WHAT'S THAT? Illus. by Harvey Mandlin. Glendale, California: Bowmax, 1968.

illus. with photographs. grades $\mathrm{K}-2$. \$3.24.

Two little boys, one English-speaking and the other spanish-speaking, enjoy a trip to the children's zoo. In the course of watching the animais, the English-speaking boy learns what to call each animal in Spanish. Adopted as a California state text in 1971 .

- WHAT IS A BIRTHDAY CHILD? Glendale, California: Bowmar, 1967.

25p. illus. with fisotographs. grades K-2. Engl. or span. ed. avail. $\$ 3.24$. paper.

Depicts the nice things that happen to a little girl on her birthday. Adopted as a california state text in 1971.

Ormsby, Virginia Ė. WHAT'S WRONG WITH JULIO? Illus. by the author. Philadelphia: J. B. Iippincott, 1965.

illus. grades $1-3 . \$ 3.79$.

Of the five Spanish-speaking children in a class, one was unhappy and did not participate. His loneliness brings about a gradual response from the children.

Serfozo, MarY. WELCOME, ROBERTO! / BIENVENIDO, ROBERTO: Illus, by John Serfozo. Chicago: Follett Publishing Co., 1969 .

$32 \mathrm{p}$. illus. with photographs. grades $\mathrm{k}-2$. bilingual. $\$ 3.15$.

Each day in kindergarten is over too soon for Roberto because it means friends, fun, and a good teacher. 
Williams, Letty. THE LITTLE RED HEN / IA PEQUEÑ GALIINA ROJA. Illus. by Herb williams. Englewood Cliffs, New Jersey: Prentice-Hall, 1969.

30p. illus. grades $\mathrm{K}-3$. bilingual. $\$ 5.75$.

The little red hen found an ear of corn and asked who would help her make tortillas out of it. The other animals would not help her, but when the tortillas were ready there were plenty of friends willing to eat them.

\section{Poetry}

Jimenez, Emma. PARA CHIQUITINES. Illus. by Gilbert Martinez. Glendale, California: Bowmar, 1969.

76p. illus. grades $\mathrm{K}-3$. bilingual. $\$ 5.95$.

A collection of Spanish language songs, poems, and finger plays for the young child. Translations at the end of each section.

Lockhart, Iinda $\mathrm{Z} .$, and Adele stinson. A ES PARA AMIGO ! $A$ IS FOR AMIGO. Illus. by John Iittleboy. Palo Alto, California: Dos Voces Press, 1974.

48p. illus. grades $\mathrm{K}-4$. bilingual. $\$ 2.25$. paper.

This is a "bilingual rhyming alphabet book", written and illustrated in a happy style. Each letter, A-Z, has a rhyme in English and Spanish, such as, "L is for IAPIZ / A pencil of lead./ It writes and it scribbles / Ideas from my head." Includes the Spanish letters $\mathrm{CH}, \mathrm{LI}, \mathbb{\mathrm { N }}$, and RR. Includes a Glossary of Spanish words.

Resnick, Seymour, ed. SPANISH-AMERICAN POETRY; A BILINGUAL SELECTION. IIlus. by Anne Marie Jauss. Irvington-on-Hudson, New York: Harvey House, 1964.

96p. illus. grades 6-8. bilingual. \$2.95.

Selections from well-known Spanish poems are given with their English translation is facing pages. Unfortunately, some of the most eminent poets are represented only by isolated stanzas from their works. 
Reference Books

MAKERS OF AMERICA. Chicago: Encyclopaedia Britannica, n.d.

10v. illus. + photos. \$83.50/set.

This set documents and surveys ethnic diversity in the United States from 1536 to the present, touching on more than 85 separate ethnic, national, and religious minorities. The 731 selections are drawn from letters, diaries, songs, public documents, newspaper editorials, magazine articles, poems, and speeches. The arrangement is chronological, and there are five indices: Ethnic, Proper Name, Topical, Illustration, and Author/source. Each volume contains a table of contents, and each chapter is introduced by an essay. Illustrated by more than 1,000 photographs and drawings. Bibliographies. Includes a set of catalog cards.

Spiegel, Shelly, and Pat Marquevich. MULTIETHNIC STUDIES I'T THE ELEMENTARY CLASSROOM. Illus. by Beatriz sustamante. Pico Rivera, California: Education in Motion, 1975.

$200+$ p. illus. $\$ 10.95$.

Presents elementary school projects and lessons designed to build positive racial attitudes through meaningful cultural experiences. Includes material in the following areas: arts and crafts; personalities; recipes; songs; holidays; patterns; bibliographies; flannel board stories; and the contributions of various ethnic groups in our society.

\section{Textbooks}

Acuña, Rudolph, and Peggy Shackelton. CULTURES IN CONFIICT; PROBLEMS OF THE MEXICAN AMERICANS. New York: Charter Book CO., 1970 .

144p. illus. + photos.

Presents the problems faced by a member of a minority culture living in a society that differs from his own. Shows how customs among Mexican Americans can result in both friction and enrichment. Utilizes numerous case studies with follow-up questions. The book is designed to help young people recognize that being different is not undesirable. Index. A teacher's guide is available. Adopted as a California state text in 1973. 
Acuña, Rudolph. THE STORY OF THE MEXICAN AMERICANS; THE MEN AND THE LAND. NeW York: American Book Co.. 1969.

140p. illus. + photos. grades 4-6. $\$ 2.60$.

Examines the culture, contributions, and influence of the Mexican Arnericans in the building of the Southwest. Photographs and biographical notes on prominent Mexican Americans are interspersed throughout. Spanish-English Glossary. Includes a teacher's guide. Adopted as a California state text in 1971.

Bay Area Bilingual Education League. IA RAZA. Berkeley: Bay Area Bilingual Education League, n.d.

\section{illus. $\$ 2.70$.}

Gives a pictorial and historical presentation of Chicano history from pre-Columbian times to the present.

Brown, and Guerra. OUR MEXICAN HERITAGE. Lexington, Massachusetts: Ginn and Co.

grades 4-8. $\$ 2.00$ (teacher's guide, $\$ 2.52$ ). paper.

Highlights early leaders of an Indian-SpanishMexican past, and some outstanding contemporary Mexican Americans. A 16-page teacher's guide includes questions, a key, and suggested activities.

Lockhart, Linda $\mathrm{z}$. , and Adele Stinson. A ES PARA AMIGO ! A IS FOR AMIGO. Illus. by John Littleboy. Palo Alto, California: Dos Voces Press, 1974.

48p. illus. grades $\mathrm{K}-4$. bilingual. $\$ 2.25$. paper. See entry under poetry for annotation.

Martinez, Gilbert, and Jane Edwards. THE MEXICAN AMERICAN; HIS LIFE ACROSS FOUR CENTURIES. Palo Alto, California: Houghton Mifflin, 1973.

illus. grades 7 and up. $\$ 2.40$ (teacher's guide, $\$ 1.50)$. paper.

This text traces Mexican and Mexican American history from the pre-Columbian period to the present, and focuses on factors that have shaped the outlook of Mexican Americans. The contributions they have made 
to Amexican society and culture, and the problems they face in a society dominated by white, Englishspeaking persons is also discussed. Touches on diverse programs and organizations. Includes discussion questions, maps, and an index. A teacher's guide is available.

Nava, Julian. MEXICAN AMERICANS; PAST, PRESENT, AND FUTURE. New York: American Book Co.. 1969.

120p. illus. + photos. grades 5-8. Engl. or span. ed. avail. $\$ 2.50$. paper.

Traces the history of Mexicans in the United States and describes their social, political, and cultural contributions to their new country. Includes a brief history of Mexico, and "problems to think about" at chapter ends. Includes maps and diagrams, an index and bibliography. Adopted as a California state text in 1973.

Stanek, Muriel, and clinton Hartmann. AMERICANS ALL, A NATION OF IMMIGRANTS. Westchester, Illinois: Benefic Press.

grades 4-6. $\$ 2.85$ (teacher's guide, $\$ 1.50$ ).

This text is designed to provide students with an understanding of the development of our country, emphasizing the role of diverse cultural groups. one chapter is devoted to Mexican Americans. A teacher's guide is available.

Sullivan, Mary W. PANCHO VILIA REBELS. Menlo Park, California: Addison-Wesley.

grades $4-8$.

This text is designed for use by reluctant readers in urban areas. The stories feature minority group teenagers in contemporary settings. Includes exercises. Adopted as a California state text. 
NONPRINT 
Audio Tapes

BLUE WILLOW by Doris Gates. University of Michigan, 1967. cassette. $15 \mathrm{~min}$. grades 4-8.

Brief introductory statement indicates that this is one of a set of children's books put on tape. First chapter of book is read with expression by a womar with a pleasant voice. Well paced; no background sounds.

CALIFORNIANS OF MEXICAN DESCENT. Colin Edwards for Pacifica Programs, 1960.

10 tapes or cassettes. $1 \mathrm{hr}$. ea. grades 7 and up. $\$ 10.50 \mathrm{ea}$. On tape, or $\$ 11.50 \mathrm{ea}$. On cassette; set of $10, \$ 88.00$.

Freelance radio journalist colin Edwards traveled up and down the state interviewing Mexican Americans in all walks of life for this voice documentary series. Others who had first hand knowledge of the accomplishments, problems and future of the Mexican Americans were also interviewed. The program tities are 1) How, When \& Why They Came; 2) The Culture They Brought; 3) Culture \& the Question of Language; 4) Drama in the Mexican Community; 5) Their Taste \& Talent in Music; 6) Their Dancers \& Artists; 7) The Matter of Taste; 8) The Mexican Family in California; 9) The Question of Faith; and 10) Their Values \& Psychology. Each program is self-contained.

CASE STUDIES IN AMERICAN TEAMWORK. Society for Visual Education, n.d.

album of 2. cassettes or records. grades 4-8. $\$ 11.50$ on records, or $\$ 15.50$ on cassettes.

The illustration of four case studies are designed to show how the unique teaming of two individuals, one of them a member of a minority group, resulted in remarkable achievements. The four cases are, Cesar Chavez/Robert Kennedy; Jackie Robinson/Branch Rickey; Jim Thorpe/Glen "Pop" Warner; Phillis Wheatley/Mary Wheatley. 
MEXICAN AMERICAN : AN EXAMINATION OF STEREOTYPES. Produced by Henry Olguin. Distributed by BFA Educational

Media, n.d.

8 cassettes. grades 7 and up.

Analyzes the origins, development, and effects of stereotyping on both Mexican Americans and Anglos.

*MEY.ICANS. Minority Groups; The Development of a Nation Series. Produced by Education Unlimited Corp. Distributed by Demco Educational Corp.. n.d.

cassette. grades $4-6 . \$ 8.50$.

\section{Calendars}

B.A.B.E.L. CALENDAR. Bay Area Bilingual Education League, 1975.

$\$ 3.00$

An artistic calendar with important Mexican American and Latino cultural events and/or biographicai information.

EI CALENDARIO CHICANO. The Southwest Network, 1975.

illus. grades 5 and up. $\$ 1.50$.

A twenty-eight page calendar suitable for wall

mounting. Gives monthly highlights of Chicano history in adaition to day by day events of significance to the Chicano. All illustrations are by Chicano artists.

MEXICANO AMERICANO CALENDARIO HISTORICO. Schlitz Brewing Co., 1975.

illus. grades 5 and up.

Large wall calendar printed in brown on cream colored paper. Theme of great men of Spanish, Mexican and Indian heritage and their significant contributions to the history of the Southwest.

\section{Film Loops}

MEXICAN AMERICANS. Ethnic Groups Series. Holt/Ealing, 1970. color. grades $1-8 . \$ 24.95$.

Depicts aspects of Mexican culture in America through 
events in the day of a Chicano family in Los Angeles. Includes teacher's guide.

\section{Eilmstrips}

THE AIIENATED AMERICAN. New York Times, Book and Educational Division, 1969.

72fx. with record (for use with manual projector only). sound. color. $16 \mathrm{~min}$. $\$ 9.00$.

Discusses those Americans who do not share in America's bounty--a situation faced by Black people, Mexican Americans, Puerto Ricans, Indians, and many others who are analyzed. Includes a teacher's guide.

AMERICA, THE MELTING POT: MYTH OR REALITY? Current Affairs, n.d.

64fr. with record or cassette. sound. color. $18 \mathrm{~min}$. $\$ 15.00 \mathrm{with}$ record, or $\$ 17.50$ with cassette.

An exploration into the validity of the "melting pot" theory of American society, and why some ethnic groups have found assimilation more difficult than others. Includes a teacher's guide.

AMERICAN FAMILIES. Coronet Films, 1969.

set of 6. approx. $45 \mathrm{fr}$. ea. with records or cassettes. sound. color. $10 \mathrm{~min}$. ea. $\$ 55.00$ with records, or $\$ 70.00$ with cassettes/set.

Pictures the daily activities and life of six urban American families of varied ethnic background. Set includes Mexican American, Puerto Rican, and Chinese families.

AMERICA'S CHILDREN. Scott Education, 1970.

single, or set of 5 . with records or cassettes. sound. color. $\$ 15.00 \mathrm{ea..}$ or $\$ 65.00 /$ set.

Depicts through the eyes of their children the racial and ethnic traditions of five minority groups who contribute to the diverse make-up of our nation. The titles are 1) Our First Americans; 2) I Am a Puerţo Rican; 3) Los de la Raza; 4) Ching Dao; and 5) To the Mountaintop. 
BAD BOY, GOOD BOY. Children's Iiterature Series. McGrawHill, n.d.

with record or cassette. sound. color. $\$ 16.00$ with record, or $\$ 18.00$ with cassette.

This filmstrip is based on the book of the same title by Marie Hall Ets. See its entry under Fiction for annotation.

BEING A CHICANO. Story of America's People Today, Part II Series. Eye Gate, n.d.

$38 \mathrm{fr}$. with record or cassette. sound. color. grades 4-6. $\$ 13.25$ with record, Ir $\$ 13.45$ with cassette.

Discusses what it is like to be Chicano. Suggests that by the third generation minorities usually associate more strongly with the American national and cultural experience and life style than with their individual sub-culture. Points up differences as well as a common heritage of being an American. A teacher's guide follows the "end" frame. Catalog cards are available.

BRAVO MARTA! The Bilingual Reading Child Series. Produced by John Figueroa. Distributed by BFA Educational Media, n.d.

1 of a set of 4 . with record or cassette. sound. color. grades $\mathrm{K}-3$. bilingual. $\$ 61.00$ with records, or $\$ 69.00$ with cassettes/set.

The Charro is a vestige of the hacienda and vaquero style of living practiced by Mexicans for generations. Marta wants to ride in the traditional Charro parade with the rest of her family, but she does not know how to ride a large horse. Because her abuelo helps her and she practices her wish comes true. Told in a mixture of both English and Spanish narration. The set includes a comprehensive teacher's guide; 20 reproducible skill sheets (in English and Spanish); and 20 activity cards (in English and Spanish). The next entry, BUENAS AMIGAS, is also part of this series. The other two filmstrips deal with a child from Puerto Rico and a child from cuba. 7 
BUENAS AMIGAS. The Bilingual Reading Child Series. Produced by John Figueroa. Distributed by BFA Educational Media, n.d.

1 of a set of 4 . with record or cassette. sound. color. grades $\mathrm{K}-3$. bilingual. $\$ 61.00$ with records, or $\$ 69.00$ with cassettes/set.

Maria Elena is from Mexico and speaks only Spanish. Christina lives in the United States and speaks only spanish and English. When the two girls meet for the first time at a playground near their homes, they discover they have something in common--their language. Through this common bond they share their worlds with each other, discovering uniqueness and similarities in their cultures. Told in a mixture of both English and Spanish narration. See preceeding annotation for series information ana inclusions.

CALIFORNIA CONFLICT: MIGRANT FARM WORKERS. FOCUS on America Series. Society for Visual Education, n.d.

with record or cassette. sound. color. grades 5-8. $\$ 12.50$ with record, or $\$ 14.50$ with cassette.

Shows the dependence of agriculturally rich central California on migrant farm workers while highlighting their lifestyle and living conditions. Discusses the beneficial effects of recent unionization. Includes a teacher's guide.

CHILDREN OF COURAGE; FIVE ORIGINAL AMERICAN ETHNIC TALES. Spoken Arts, 1971.

set of $5.72 \mathrm{fr}$. with records or cassettes. sound. color. $\$ 100.00$ with records, or $\$ 110.00$ with cassettes/ set.

Entertaining and original American ethnic tales designed to instill pride of origin in children. Representing Mexican Americans is the tale, "Pancho's Puppets" a Fantasy involving a witch who turns Pancho into a burro. Other tales in the set include a Black, Puerto Rican, American Indian, and Japanese American child as hero or heroine. Includes a teacher's guide. 
COLONIA-THE MEXICAN AMERICAN. Accent on Ethnic America Series. Multi-Media Productions, n.d.

with record or cassette. sound. color. \$12.95 with record, or $\$ 14.95$ with cassette.

The Mexican American is the third largest minority in the U.S., with a centuries-old culture. Yet, to many, he is little more than the comic "Cisco Kid" or the ubiquitous "bad-man" of cowboy movies. Long exploited as a cheap and plentiful source of labor, today he struggles to be--and have--what the word "American" should connote, and still preserve his heritage. This message is conveyed through photography, art renderings, maps, graphs, and cartoons. Includes a teacher's guide, and catalog cards are available.

THE CULTURE OF THE MEXICAN AMERICANS / IA CUL. D: : $:$ LOS NORTEAMERICANOS DE ORIGEN MEXICANO. EduCi....? Filmstrips, 1973 .

with cassette. sound or silent. color. $5:-8$ Engl. or Span. ed. avail. \$\$7.50/silent, or with cassette.

An approach to an explanation of the cuiture " the Mexican Americans written by Dr. Carlos Monsanco of the University of Houston.

ERNESTO, MEXICAN AMERICAN BOY. Chilaren of the Inner City Series. Society for Visual Education, 1970.

70 fr. with record or cassette. sound. color. 17 min. grades $2-5$. \$11.00 with record, or $\$ 13.00$ with cassette.

Photographed in an inner-city neighborhood this vignette presents the activities, customs, background, and unique problems of a Mexican American boy as a member of an ethnic group.

GILBERTO AND THE WIND. Weston Woods, 1969.

$34 \mathrm{fr}$. with record or cassette. sound. color. grades $\mathrm{k}-3$. $\$ 9.20$ with record, or $\$ 12.75$ with cassette.

Uses illustrations from the book of the same title by Marie Hall Ets, accompanied by picture-cued text booklet. See book entry under picture Books for annotation. Also entered under Motion Pictures and Recordings. 
IN THE CITY--THE MEXICAN AMERICANS. LONg Filmslide Service, n.d.

40 fr. silent. color. \$6.00.

Shows how the Mexican American contributes to the life and culture of the city in which he lives. Captioned.

LA LENGUA / THE SPANISH IANGUAGE. Urban Media Materials, 1972 .

set of 4. with records or cassettes. sound. color. grades 4-8. bilingual. \$61.00 with records, or $\$ 65.00$ with cassettes/set.

Presents the background of those who speaks Spanish; where and why; bilingual signs; and functional Spanish, English and Spanish signs compared. Narration in English and Spanish. Includes a teacher's guide. catalog cards are available.

IA RAZA: THE HISTORY OF THE CHICANO. Multi-Media Productions, 1969.

set of 6-8. with records. sound. color.

A survey of the Mexican American and his heritage from past conquest to present awakening and to cultural and political potentials.

IA RAZA, THE MEXICAN AMERICANS. Multi-Media Productions, n.d.

set of 24. with records. sound. color. $8 \mathrm{hr}$. Engl. or Span. ed. avail. $\$ 235.00 /$ set in one language. $\$ 324.50 /$ set in both languages.

An in-depth treatment of the history of the Mexican American covering the spectrum from pre-Columbian society to the present. Frequent planned discussion stops allow for student particination, and a detailed teacher's guide accompanies the set. The program was developed in cooperation with the Southwest Council of La Raza and uses authentic visuals throughout, including codices, old prints, and photographs. Original music composed and sung by Miguel Barragan. 
IOS DE IA RAZA. Jam Handy School Service Center, Scott Education Division, n.d.

52 fr. with record or cassette. sound. color. \$5.00 with record, or $\$ 7.00$ with cassette.

Portrays the Bravos, a Mexican American family who affirm their heritage, but seek a better life.

THE MEXICAN AMERICAN. The other American Minorities Series. Teaching Resources Films, n.d.

with record or cassette. sound. color. grades 4-8. $\$ 14.50$ with record, or $\$ 17.50$ with cassette.

Treats the special problems and aspirations of Mexican Americans as a minority group. Emphasizes recent activism. Includes a teacher's guide.

MINORITIES HAVE MADE AMERICA GREAT, PART II. Warren Schloat Productions, 1968.

set of 6. approx. $90 \mathrm{fr}$. ea. with records or cassettes. sound. color. approx. $17 \mathrm{~min}$. ea. grades 4-8. $\$ 92.00$ with records, or $\$ 110.00 \mathrm{with}$ cassettes/set.

The filmstrip "Mexican Americans" details their contributions to the English language and cattle ranching; also explores discrimination against migrant workers and current Chicano conditions. Part II also includes two filmstrips on American Indians, two on Puerto Ricans, and one on Orientals. Includes a teacher's guide; catalog cards are available.

PACO AND HIS PAINTING PAIS. Urban Media Materials, n.d. with record or cassette. sound. color. grades 1-4. bilingual. $\$ 15.50$ with record, or $\$ 17.50$ with cassette.

A tale of boys building their own clubhouse on a vacant lot and how bright colors save the day. Narrated in English and Spanish. Includes a teacher's guide; catalog cards are available.

OUT OF THE MAINSTREAM. Produced by Richard W. Bruner. Distributed by Warren Schloat Productions, 1970.

set of 6. with records or cassettes. sound. color. $\$ 92.00$ with records, or $\$ 110.00 \mathrm{with}$ cassettes/set.

First person accounts of problems of citizens outside the mainstream of United states society suffering 
from poverty, discrimination, and oppression. Treats a New York Puerto Rican, a black migrant, a white Appalachian, a Mexican American, a Southern black farmer, and a sioux Indian. Includes a teacher's guide.

PIIGRIMAGE. Multi-Media Productions, n.d.

set of 2. with record. sound. color. $\$ 30.00 /$ set.

Relates the story of the march to sacramento during the Delano grape strike.

PIÑTA. Five Families Series. Scholastic, n.d.

$60 \mathrm{fr}$. with record or cassette. sound. color. grades $\mathrm{k}-3$. Engl. or bilingual. $\$ 17.00$ with record, or $\$ 19.00$ with cassette.

A piñata party in Phoenix includes making tortillas and a ride on Uncle Manuel's fire truck. Includes a teacher's guide, color photograph, and poster.

PORTRAIT OF A MINORITY: SPANISH-SPEAKING AMERICANS. Associated Press--Special Reports Series. Scott Education, 1972 .

set of 2. approx. $90 \mathrm{fr}$. ea. with records or cassettes. sound. color. $\$ 39.00 /$ set.

Examires both the common and individual problems of America's three largest Spanish-speaking groups, while tracing the history of the Spanish-speaking sub-culture and its influence on America. Looks at differences, goals, and problems. Includes a teacher's guide.

THE SPANISH AMERICANS OF NEW MEXICO. FOCus On America Series. Society for Visual Education, n.d.

with record or cassette. sound. color. grades 5-8. $\$ 12.50$ with record, or $\$ 14.50$ with cassette.

Examines the causes for conflict between the descendents of Land Grant Spanish settlers and the United States government. Shows modern society's threat to a traditional way of life. 
SPANISH AMERICAN LEADERS OF 2OTH CENTURY AMERICA. BFA Educational Media, 1970.

set of 8 . approx. 53 fr. ea. with records or cassettes. sound. color. grades 7 and up. $\$ 84.00$ with records, or $\$ 96.00$ with cassettes.

Presents the biocraphies of four Mexican Americans and four puerto Ricans in the fields of labor relations, politics, the arts, and education. The motif of the series is: though handicapped by poverty, lack of education, physical disabilities and discrimination, these men surmounted these obstacles to make significant contributions to American life.

THE STORY OF THE SPANISH-SPEAKING AMERICAN. The Story OE America's People--Series One. Eye Gate, n.d.

41 fr. with cassette. sound or silent. color. grades $3-6$. $\$ 6.50 /$ silent, or $\$ 12.45$ with cassette.

Focuses on the arrival, history, achievements, and unique contributions of Spanish-speaking Americans. The series is a recipient of the Freedoms Foundation Award. Catalog cards are available.

VIVA LA CAUSA: THE MIGRANT LABOR MOVEMENT. DenOyerGeppert Audio-Visuals, n.d.

set of 2. $60 \mathrm{fr}$. ea. with records or cassettes. sound. $20 \mathrm{~min}$. ea. grades 7 and up. $\$ 34.00 / \mathrm{set}$.

Through a series of interviews with migrant workers and union organizers, this program traces the rise of Cesar Chavez's farm labor movement. Attests to the successful use of non-violence to achieve social and economic reforms. Though weary from the long struggle, migrant workers remain hopeful that their first gains are by no means their last. Includes a teacher's guide; catalog cards are available.

Kits

BROWN STUDIES. Creative Activity Series. Distributed by Marie's, n.d.

$\$ 5.95$

Each activity card contains projects, games, experiments, observations and questions. Emphasis is on self inquiry. 
SPANISH-SPEAKING PEOPLE HAVE HELPED TO BUIID AMERICA. Media Material, Inc., 1973.

grades $4-7$.

Designed to develop awareness of Spanish-speaking people's heritage and their contributions to life in America. Includes one cassette, a teacher's guide, 35 student booklets, and post test.

VIVA IA RAZA: THE MEXICAN AMERICAN EXPERIENCE IN THE SOUTHWEST. Noble and Noble, n.d.

A Springboarās Programs Learning Kit including a teacher's guide, posters, printed matter, and worksheets.

\section{Motion Pictures}

ADOBE CITY. Produced by John S. Candelario for McGrawHill, n.d.

sound. color. $15 \mathrm{~min}$. $\$ 7.50 /$ rental; $\$ 150.00 / \mathrm{sale}$.

Santa Fe, the capital of New Mexico, is a city of three cultures: Indian, Spanish, and Anglo. Since 1610 it has witnessed the making of history. Its adobe buildings possess an old world charm unique among American cities. Many historic landmarks made of mud remain to give testimony to the lasting quality of adobe architecture. Film goes on to show how adobe is made today, and how it was made by the Indians in pre-spanish days.

AND NOW MIGUEL. Note: There is more than one version of this film, about which information pertaining to its availability differs from one producer to the next. Since it is not clear which is the most up-todate source, and since one is a free loan, two are rentals, and one is offerted on a sale basis, in the interest of complete coverage all four entries are listed below (even though they state conflicting information in part).

- Norwood Films, n.d.

sound. b\&w. $70 \mathrm{~min}$. grades 4 and up. $\$ 133.00 / \mathrm{sale}$.

Based on Joseph Krumgold's Newberry Award winning book of the same title, this film relates the story of a family in the southwest to whom the traditions 
of sheep-raising have come down through generations. It portrays their family life and the fulfillment of young Miguel's dream of being accepted on an equal plane by his father and older brothers. (Also entered under Fiction.) See note above. - MCGraw-Hill Films, 1953.

sound. b\&w. 63 min. grades 4 and up. rental only. "Until recently this film was available for sale from the National Audiovisual Center; however, since it was originally produced by the USIA and all USIA materials have been withdrawn from distribution in the U.S. it is currently not available for purchase." see annotation and Note above.

- Produced by Robert Radnitz for UniversalInternational, 1966.

sound. color. $95 \mathrm{~min}$. grades 4 and up. $\$ 37.50 /$ rental only.

Stars Guy stockwell, Pat Cardi, and clu Gulager. Directed by James B. Clark. Screenplay by Ted Sherdeman and Jane klove. Photography by Clifford Stine. Music by Phillip Lambro. See annotation and Note above. Iibrary.

General Telephone Company of California, Film

sound. b\&w. 63 min. grades 4 and up. may be borrowed free from their Film Library within their telephone service areas.

See annotation and Note above.

CALIFORNIA'S DAWN, PARTS I \& II. Ernest Kleinberg Productions, n.d.

color. $14 \mathrm{~min}$ ea. $\$ 275.00 / \mathrm{sale}$.

The history of California through the raising of the Bear Flag is told in old paintings and drawings. Subdued narration. Especially appropriate to a study of the Spanish and Mexican heritage of the state. 
CHICANO. Produced by J. Gary Mitchell. Distributed by BFA Educational Media, 1971.

sound. color. $23 \mathrm{~min}$. grades 7 and up. $\$ 25.00 /$ 3-day rental; $\$ 315.00 /$ sale.

The narration of this film consists of interviews with Mexican Americans in different walks of life. From a sociological orientation it explores various manifestations of bias, discrimination, and oppression, and presents the goals of various Chicano organizations.

CHICANO. Produced by Paul Marshal1. Distributed by MCGraw-Hill Films, 1970 .

scund. color. 27 min. grades 7 and up. $\$ 29.00 /$ rental; $\$ 350.00 /$ sale.

A documentary including interviews with Chicano poets, teachers, and labor organizers. Designed to shed light on the problems, experiences, heritage, life style, and attitudes of Mexican Americans as a group. Includes a guide.

CHICANO FROM THE SOUTHWEST. Encyclopaedia Britannica Educational Corp., 1970.

sound. b\&w or color. 15 min. grades 5 and up. $\$ 68.00 / \mathrm{bsw} / \mathrm{sale}$; $\$ 167.50 /$ color/sale.

A rural Mexican American family moves to Los Angeles, but life in an urban barrio is accompanied by problems and adjustments. Told by the young son with flashbacks to life in Texas crop workers.

DECISION AT DEIANO. Produced by Jack L. Copeland. Distributea jy Henk Newenhouse Cathedral Films, 1967. sound. color. $26 \mathrm{~min}$. grades 7 and up. $\$ 385.00 / \mathrm{sale}$.

A documentary about the early efforts of Cesar Chavez to organize the farm workers, and the grape boycott which led to the first collective bargaining election in the history of American agriculture. Interviews with both sides--workers and growers--are shown. 
FELIPA : NORTH OF THE BORDER. Many Americans Series. Bert Salzman Production. Distributed by Learning Corporation of America, 1970.

sound. color. $17 \mathrm{~min}$. grades 5-8. \$210.00/sale.

Story of a young Mexican American girl and her uncle who has injured his back working as a crop picker in the fields of Arizona. His chance to get a new job as a truck driver depends on him learning English and passing a driver's license test. Because Felipa is bilingual and hopes to someday become an English teacher, she determines to teach him herself.

GILBERTO AND THE WIND. Reading Incentive Film Series. MCGraw-Hill Films, 1967.

sound. color. $7 \mathrm{~min}$. grades $\mathrm{k}-3 . \$ 95.00 / \mathrm{sale.}$

Harry Belafonte reads the book of the same title by Marie Hall Ets, with close-ups of the book's lovely illustrations. See also entries for this same work under Filmstrips, Picture Books, and Recordings.

THE HANDS OF MARIA. RMI Film Productions, n.d.

color. $17 \mathrm{~min} . \$ 150.00 / \mathrm{sale}$.

Maria Martinez, a Pueblo potter, fashions large pieces without the aid of a potter's wheel by building coiling ropes of clay as did her ancestors. Her techniques have brought her recognition and fame; she has been honored by the American Institute of Architects. The film was written and photographed by Dr. J. Donald McIntyre and released by courtesy of the Kansas City, Missouri Museum.

HENRY: BOY OF THE BARRIO. BFA Educationál Media, 1968.

sound. b\&w. $25 \mathrm{~min}$. grades 7 and up. $\$ 12.00 /$ rental; $\$ 165.00 /$ sale.

A two-year study of a young Mexican American boy entering his teans in a Los Angeles barrio. His mother is Indian, his heritage is Mexican, and the society surrounding him is Anglo. 
HISPANIC CUITURAI CONTRIBUTIONS. Hispanic Series. Produced by Denver Public Schools. Distributed by western Cine Service, 1967.

color. $25 \mathrm{~min} . \$ 150.00 / \mathrm{sale}$.

Traces Hispanic influence on our language, art, music, and dance. Includes a teacher's guide.

HISPANIC HERITAGE. Hispanic Series. Produced by Denver Public Schools. Distributed by Western Cine Service, 1967.

color. $25 \mathrm{~min} . \$ 150.00 / \mathrm{sale}$

Through the music of guitarist, Alex Chavez, the past and present of Hispanic heritage is introduced.

Includes a teacher's guide.

HISPANIC LIFE IN THE CITY. Hispanic Series. Produced by Denver Public Schools. Distributed by Western Cine Service, 1967.

color. $22 \mathrm{~min}$. $\$ 150.00 / \mathrm{sale}$

Shows role models of successful Denver spanish surnamed citizens in such jobs as judges, educators, and state senators. Includes a teacher's guide.

HUELGA: MCGraw-Hill Films, 1967.

sound. color. $50 \mathrm{~min}$. $\$ 30.00 /$ rental; $\$ 575.00 / \mathrm{sale}$.

Documents the genesis of the Delano grape strike of Mexican and Philippino American farmworkers in the San Joaquin Valley in 1965. Also surveys the advances of the National Farm Workers Association.

HUELGA MARCH. American Documentary Films, n.d.

b\&w. 15. min. $\$ 100.00 /$ sale.

Covers the same ground as the preceeding film, but in a shorter time. Narrated by Cesar Chavez. 
THE IAND IS RICH. American Documentary Films, n.d.

b\&w. $25 \mathrm{~min} . \$ 200.00 / \mathrm{sale}$

Treats the history of migrant labor and strikes in California with particular emphasis on the Delano grape strike. The entire labor movement of the state serves as background and gives perspective to the United Farm Workers Organizing Committee.

MAKING A PIÑATA. Atlantis Productions, n.d.

color. $11 \mathrm{~min}$.

A useful film which illustrates clearly, step by step. how to make a piñata with simple materials available in most homes.

MEXICAN AMERICAN CULTURE: ITS HERITAGE. Communications Group Nest, 1970 .

sound. color. $18 \mathrm{~min}$. grades 5 and u.p. Engl. or span. ed. avail. $\$ 225.00 /$ sale.

Traces the history of Mexico and its relationship with the U.S.--especially the Southwest. Events in Mexican history are seen throughout map;, photographs and paintings. Depicts aspects of Mexican culture such as dance, art, and music which have been influential. Ricardo Montalban narrates.

A MEXICAN AMERICAN FAMILY. Atlantis Productions, n.d.

color. $16 \mathrm{min.} \$ 200.00 / \mathrm{sale}$.

A brief look at the history of Mexican Americans in the Sculliwest is followed by a look at the daily activities of several members of a Chicano family-at work, in school, together in the evenings, and in church.

THE MEXICAN AMERICAN FROM THE REVOLUTION TO THE PRESENT. Bilingual Educational Services, n.d.

sound. color. $10 \mathrm{~min}$. Engl. or span. ed. avail. $\$ 120.00 /$ sale.

Covers the history of the Mexican American from the Mexican Revolution to modern times. Defines current problems. 
THE MEXICAN AMERICAN HERITAGE AND DESTINY. Handel Film Corp.. 1970.

sound. color. 29 min. grades 5-8. Engl. or Span. ed. avail. $\$ 350.00 /$ sale.

Aims at building pride and respect among Mexican Americans by showing the unique cultural achievements in Mexico's history, as well as highlighting the successes of Mexican Americans in the mainstreams of U.S. society. Ricardo Montalban narrates. Recommended by the cabinet Committee on opportunity for the spanish speaking.

Library .

General Telephone Company of California, Film

sound. color. $29 \mathrm{~min}$ grades 5-8. may be borrowed free from their Film Library within their telephone service areas.

See annotation above.

MEXICAN AMERICAN: INVISIBLE MINORITY. PARTS I \& II. Indiana University, n.d.

sound. color. $18 \mathrm{~min}$. ea. $\$ 13.00 /$ rental; $\$ 300.00 /$ sale.

Ernesto Galarza, Sal Castro, Corky Gonzales, Reies Tijerina, and Cesar Chavez express their views in this summary film dealing with the responses, problems, and aspirations of Mexican Americans.

MEXICAN AMERICANS: QUEST FOR EQUALITY. Anti-Defanation League of B'Nai B'Rith, n.d.

sound. b\&w. $28 \mathrm{~min} . \$ 100.00 / \mathrm{sale}$.

An account of the Mexican American and his unceasing efforts to achieve full equality is presented in this film by author-educator, Dr. Ernesto Galarza.

MEXICAN AMERICANS: VIVA LA RAZA. MCGraw-Hill Films, n.d. sound. b\&w. $47 \mathrm{~min}$. \$27.00/rental; $\$ 310.00 / \mathrm{sale}$. Grievances of the riexican American community in Los Angeles are discussed by political and religious leaders, the police, and Chicano leaders--both moderate and militant. The success of leaders such as cesar 
Chavez and Rudolfo Gonzales is seen as a major force in the struggle for economic and social advancement. (Inciudes a violent confrontation between the Brown Berets and the police.)

MINORITY YOUTH: ANGIE. Minority Youth Series. A stuart Roe Film. Distributed by BFA Educational Media, 1971.

sound. color. $10 \frac{1}{2} \mathrm{~min}$. grades 5 and up. $\$ 8.00 /$ 3-day rental; $\$ 145.00 /$ sale.

A young girl relates her personal feelings about being a Mexican American. Though she is conscious of prejudice in education and employment opportunities, she feels that ora cannot change society "on one saturday."

NORTH FROM MEXICO: EXPLORATION AND HERITAGE. Produced by the Center for Mass Communication of Columbia University Press. Distributed by Greenwood Productions, 1971.

sound. color. $20 \mathrm{~min}$. grades 7 and up. $\$ 250.00 / \mathrm{sale}$.

A geographical, rather than sociological, treatment of Mexican American history and culture. Beautiful photography depicts the northward migration from Mexico to the Southwestern U.S. Sections deal with protest, labor unions, field workers, higher education; emphasizes the turn from suppression to opportunity.

NORTH OF THE BORDER. Frith Films, 1971.

color. $19 \mathrm{~min}$ grades $4-8$.

Discusses the problems facing the Mexican American and relates some of the contributions they have made to the United states.

SI SE PUEDE. Farm Worker Fund, n.d.

color. $45 \mathrm{~min}$. Engl. or Span. ed. avail. $\$ 47.50 /$ rental; $\$ 475.00 /$ sale.

Traces the 24-day fast of Cesar Chavez in Arizona, and the organizing campaign that grew out of it. supporters such as Joan Baez, Joseph Kennedy. Senator George McGovern, and Mrs. Coretta King appear in the film. 
VOICE OF IA RAZA. William Greaves Productions, n.d. sound. color. $60 \mathrm{~min}$. $\$ 380.00 / \mathrm{sale}$ (or loaned free from the Equal Employment Opportunities Commission).

Explores the problem of job discrimination and unemployment in the Spanish-speaking community. The film utilizes unrehearsed interviews, role-playing, appearances by Anthony Quinn and Rita Moreno, conversations with government officials, and unedited behind-the-scenes clips from the production of the film itself, to offer various perceptions of employment and socioeconomic conditions. Narrated by Anthony Quinn.

Yo SOY CHICANO. Indiana University, n.d.

color. $59 \mathrm{~min}$.

A comprehensive film covering the history and current status of Mexican Americans which treats many topics not mentioned in other works (e.g., the Chicano casualty rates in the Korean and Vietnam wars, the zoot suit riots, and La Raza Unida Party). Good technical quality.

Pictures, Posters, and Study Prints

CHICANOS Y CHICANAS PROMINENTES. Educational Consulting Associates, n.d.

set of 24. grades 4 and up. bilingual. $\$ 10.00 /$ set.

Portraits with biographical sketches. Introduction by Dr. Ernesto Galarza.

THE CONTEMPORARY MEXICAN AMERICAN OF ALI AGES. Distributed by El Dorado Distributors, n.d.

set of 9 . bilingual. $\$ 8.95 /$ set.

Portraits with biographical sketches. 
LIVING TOGETHER IN AMERICA. David C. Cook Publishing Co., n.a.

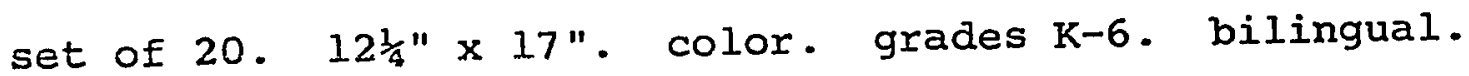
$\$ 6.75 /$ set.

A picture presentation of the many cultures within the United states, supplying information on origins, customs, celebrations, contributions, food, daily life, and achievements. Coverage is in three categories: People, Contributions, and Americans all. Includes stores and poems. A 40-page teacher's guide tells about American Indians; Mexican Americans; Puerto Ricans, Cubans; Blacks; Chinese; Japanese; Appalachians (Scotch and English); Irish; Jews; Italians; other Europeans; and Hawaiians.

MEXICAN AMERICAN CHIIDREN. Moreno Educational Co., 1971. set of 5. 9" $513 "$. b\&w. $\$ 4.95 /$ set.

Drawings.

MEXICAN AMERICANS. Moreno Eäucational Co., n.d.

Photo with biographical cameo.

OUTSTANDING AMERICANS OF MEXICAN DESCENT. Educational Consulting Associates, 1970.

set of 37. 11" $\times 14 "$. b\&w. grades 4 and up. bilingual. $\$ 15.75 /$ set.

Portraits and biographical cameos of Mexican American politicians, labor leaders, educators; sports figures, civic leaders, and business and professional men.

SPANISH SPEAKING AMERICANS. Audio Visual Enterprises, n.d. set of 12. 11" x 14". color. grades 4 and up. bilingual. $\$ 15.00 /$ set.

Two additional black and white portraits are on the reverse side of each color portrait. Biographical material on verso also. Includes such persons as Senator Joseph Montoya, Vikki Carr, Carlos Teran, Anthony Quinn, Romana Banuelos, Lee Trevino, Hector Garcia, Elena Salinas, Jose Ferrer, Armando Rodriguez, Horacio Rivero, Raymond Telles, and others. (The title of this set varies; also called AMERICANS OF MEXICAN ORIGIN PRINTS.) 


\section{RECORDIÑGS}

CASE STUDIES IN AMERICAN TEAMWORK. SOciety for Visual Education, n.d.

album of 2. records or cassettes. grades 4-8. $\$ 11.50$ on records, or $\$ 15.50$ on cassettes.

See entry under Audio Tapes for annotation.

GILBERTO AND THE WIND. Weston, Connecticut: Weston Woods, 1969 .

7". $7: 04 \mathrm{~min} .331 / 3 \mathrm{rpm}$. grades $\mathrm{K}-3 . \quad \$ 1.95$.

John Cunningham reads the book of the same title by Marie Hall Ets, with original background music by Howard Rovics. See also entries for this same work under Filmstrips, Motion Pictures, and Picture Books.

SPANISH AMERICAN CHILDREN'S SONGS. TaOS, NeW Mexico: Cantemos Records, n.d.

$331 / 3 \mathrm{rpm}$. bilingual. $\$ 3.98$.

Contains children's songs of the Southwest and Mexico. Jenny Vincent sings in Spanish and English Mi Chacra (My Farm); El Coqui (The Frog); El Zapatero (The Shoemaker); Cradie Song; and others. Includes a bilingual booklet of song words.

Slides

SLIDE PRESENTATION BY JEARL B. NUNNELEE. Arkansas Valley, Colorado, Board of Cooperative Educational Services, 1968 .

$60 \mathrm{~min}$.

Provides an in-depth look at Mexican American family life in the Arkansas valley area of Colorado.

SLIDE PRESENTATION BY REV. JOSEPH TORRES. Regis college, 1969.

$60 \mathrm{~min}$.

Provides an overview of the Colorado Hispano population. 


\section{LIST OF ABBREVIATIONS}

\begin{tabular}{|c|c|}
\hline approx. & approximately \\
\hline avail. & available \\
\hline b\&w & black and white \\
\hline Co. & Company \\
\hline Corp. & Corporation \\
\hline ea. & each \\
\hline ed. & edition, editor \\
\hline Engl. & English \\
\hline ESL & English as a second language \\
\hline fr. & Erames \\
\hline hr. & hour, hours \\
\hline illus. & illustrated, illustrations \\
\hline $\min$. & minutes \\
\hline n.d. & no date \\
\hline p. & page, pages \\
\hline paper. & paperback \\
\hline photos. & photographs \\
\hline Span. & Spanish \\
\hline v. & volumes \\
\hline$"$ & inches \\
\hline * & not available for annotation \\
\hline+ & plus \\
\hline
\end{tabular}


DIRECTORY OF SOURCES 


\section{DIRECTORY OF SOURCES}

AARDVARK MEDIA, INC., $1200 \mathrm{Mt}$. Diablo Boulevard, Walnut Creek, California 94596

ABELARD-SCHUMAN, LTD., 257 Park Avenue South, New York, New York 10010

ABINGDON PRESS, 201 Eighth Avenue South, Nashvi-1le Tennessee 37203

ADDISON WESLEY PUBLISHING COMPANY, 2725 Sand Hill Road, Menlo Park, California 94025

AILYN AND BACON, INC., Ralston Park, Belmont, California 94002

AMERICAN BOOK COMPANY, 450 west 33 rd street, New York, New York 10001

AMERICAN DOCUMENTARY FIIMS, INC., 379 Bay street, San Francisco, California 94133

ANTI-DEFAMATION LEAGUE OF B'NAI B'RITH, 315 Lexington Avenue, New York, New York 10016

ATHENEUM PUBLISHERS, 122 East 42nd street, New York, New York 10017

AUDIO VISUAL ENTERPRISES, 911 Laguna Road, Pasadena, California 91105

AVON BOOKS, 959 Eighth Avenue, New York, New York 10019 BANTAM BOOKS, INC., 666 Fifth Avenue, New York, New York 10019

BAY AREA BILINGUAL EDUCATION LEAGUE, 1414 walnut street, Room 13, Berkeley, California 94709

BENEFIC PRESS,. 10300 West Roosevelt Road, Westchester, Illinois 60153

BETHANY PRESS, BOX 179, 2640 Pine Boulevard, st. Louis, Missouri 63166

BFA EDUCATIONAL MEDIA, 2211 Michigan Avenue, Santa Monica, California 90404 
BILINGUAL EDUCATIONAL SERVICES, 1508 Oxley Street, South Pasadena, California 91030

BOWMAR PUBLISHING CORPORATION, 622 Rodier Drive, Glendale, California 91201

CANTEMOS RECORDS, TaOs, New Mexico

CENTER FOR MASS COMMUNICATION, COLUMBIA UNIVERSITY PRESS (See Greenwood Press)

CHARTER BOOK COMPANY, 1120 Avenue of the Americas, New York, New York 10036

CHILDREN'S PRESS, 1224 West Van Buren Avenue, Chicago, Illinois 60607

COMMUNICATIONS GROUP WEST, 6430 sunset Boulevard, Suite 618, Hollywood, California 90017

DAVID C. COOK PUBLISHING COMPANY, 850 North Grove Avenue, Elgin, Illinois 60120

CORONET FILMS, 65 East South water street, Chicago, Illinois 60601

CREATIVE EDUCATIONAL SOCIETY, INC., Mankato, Minnesota

THOMAS Y. CROWELL COMPANY, 666 Fifth Avenue, New York New York 10019

THE JOHN DAY COMPANY, INC., 257 Park Avenue South, New York, New York 10010

DELACORTE PRESS, 1 Dag Hammarskjold Plaza, 245 East 47 th Street, New York, New York 10017

DELI PUBLISHING COMPANY, INC., I Dag Hammarskjöld Plaza, 245 East 47 th street, New York, New York 10017

DEMCO EDUCATIONAI CORPORATION, BOX 1488, Madison, Wisconsin 53701

DENOYER-GEPPERT AUDIO-VISUALS, 5235 Ravenswood Avenue, Chicago, Illinois 60640

DENVER PUBLIC SCHOOLS, DEPARTMENT OF INSTRUCTIONAL SERVICES, 900 Grant Street, Denver, Colorado

THE DIAL PRESS, INC., 1 Dag Hammarskjöld Plaza, 245 East 47 th Street, New York, New York 10017 
DODD, MEAD AND COMPANY, 79 Madison Avenue, New York, New York, 10016

DOS VOCES PRESS, P. O. Box 10026, Palo Alto, California 94303

DOUBLEDAY AND COMPANY, INC., 501 Franklin Avenue, Garden City, Long Island, New York 11530

E. P. DUTTON AND COMPANY, INC.; 201 Park Avenue South, New York, New York 10003

EDUCATION IN MOTION, P. O. BOX 224, PiCO Rivera, California 90660

EDUCATIONAL CONSULTING ASSOCIATES, BOX 1057, Menlo Park, California 94025

EL DORADO DISTRIBUTORS, 2489 Mission Street, San Francisco, California

ELK GROVE PRESS, INC., P. O. BOX 1637, Whittier, California 90603

ENCYCLOPAEDIA BRITANNICA EDUCATIONAL CORPORATION, 425

North Michigan Avenue, Chicago, Illinois 60611

EQUAL EMPLOYMENT OPPORTUNITY COMMISSION, $1800 \mathrm{G}$ street, N.W., Washington, D.C. 20506

EYE GATE, 146-01 Archer Avenue, Jamaica, New York 11435

FARM WORKER FUND, NATIONAL FARM WORKERS SERVICE CENTER, INC., BOX 48, Keene, California 93531

FARM WORKER PRESS, INC., BOX 1060, Delano, California

FARRAR, STRAUS AND GIROUX, INC., 19 Union Square West, New York, New York 10003

FEARON PUBLISHERS, 6 Davis Drive, Belmont, California 94002

FOLIETT PUBLISHING COMPANY, 1010 west Washington Boulevard, Chicago, Illinois 60607

FOUR WINDS PRESS, 50 West 44th Sicreet, New York, New York 10036

FRIENDSHIP PRESS, 475 Riverside Drive, New York, New York 10027 
FRITH FILMS, P. O. Box 424, Carmel Valley, California 93924 GARRARD PUBLISHING COMPANY, 1607 North Market street, Champaign, Illinois 61820

GENERAL TELEPHONE COMPANY, 15900 LOS Gatos Boulevard, Los Gatos, California 95030

GINN AND COMPANY, 191 Spring Street, Lexington, Massachusetts 02173

GOLDEN GATE JUNIOR BOOKS, 8344 Melrose Avenue, LOS Angeles, California 90069 GREENWOOD PRESS, 51 Riverside Avenue, Westport, Connecticut
06880

GROSSET AND DUNLAP, INC., 51 Madison Avenue, New York, New York 10010

HANDEL FILM CORPORATION, 8730 Sunset Boulevard, West Hollywood; California 90069

HARCOURT, BRACE JAVANOVICH, INC., 757 Third Avenue, New York, New York 10021

HARPER AND ROW PUBLISHERS, INC., 10 East 53rd Street, New York, New York 10022

HARVEY HOUSE, INC ., SOuth Buckhout Street, Irvington-OnHudson, New York 10533

HILL AND WANG, 19 Union Square West, New York, New York 10003 HOLT/EALING, HOLT, RINEHART AND WINSTON, INC., Media Department, Box 3670, Grand Central Station, New York, New York 10017

HOUGHTON MIFFLIN COMPANY, 777 California Avenue, Palo Aito, California 94304

INDIANA UNIVERSITY, Audio Visual Center, Bloomington, Indiana $47 \subseteq 01$

ERNEST KLEINBERG PRODUCTIONS, 3890 Edgeview Drive, Pasadena, California 91107

IANTERN PRESS, INC., 354 Hussey Road, Mount Vernon, New York 10552 
LEARNING CORPORATION OF AMERICA, 71 I Fifth Avenue, New: York 10022

LERNER PUBLICATIONS COMPANY, 241 First Avenue North, Minneapolis, Minnesota 55401

LITTLE, BROWN AND COMPANY, 34 Beacon Street, Boston, Massachusetts 02106

J. B. IIPPINCOTT COMPANY, East Washington Square, Philadelphia, Pennsylvania 19105

LONG FILMSLIDE SERVICE, 7505 Fairmount Avenue, El Cerrito, California

LONGMANS, GREEN, INC., 72 Fifth Avenue, New York, New York 10011

LOTHROP, LEE AND SHEPARD COMPANY, 105 Madison Avenue, New York, New York 10016

MCGRAW-HILL BOOK COMPANY and MCGRAW-HILI FILMS, 1221

Avenue of the Americas, New York, New York 10020

DAVID MCKAY COMPANY, INC., 750 Third Avenue, New York, New York 10017

THE MACMILIAN COMPANY, 866 Third Avenue, New York, New York 10022

MARIE'S EDUCATIONAL MATERIALS, INC., 193 South Murphy Avenue, Sunnyvale, California

MEDIA MATERIAL, INC., 2936 Remington Avenue, Baltimore, Maryland

JULIAN MESSNER, 1 West 39th Street, New York, New York 10018 MORENO EDUCATIONAL COMPANY, P. O. BOX 22029, San Diego, California 92122

WILLIAM MORROW AND COMPANY, INC., IO5 Madison Avenue, New York; New York 10016

MULTI-MEDIA PRODUCTIONS, INC., P. O. BOX 5097, stanford, California 94305

HENK NEWENHOUSE CATHEDRAI FIIMS, 1825 Willow Road, Northfield, Illinois 60093 
NEW YORK TIMES, BOOK AND EDUCATIONAL DIVISION, 10 East $53 r d$ Street, New York, New York

NOBLE AND NOBLE PUBLISHERS, INC., I Dag Hammarskjöld Plaza, 245 East 47 th Street, New York, New York 10017

NORWOOD FIIMS, 5104 Frolich Lane, Tuxedo, Maryland 20781 OXFORD UNIVERSITY PRESS, INC., 16-00 POllitt Drive, Fair Lawn, New Jersey 07410

PACIFICA PROGRAMS TAPE LIBRARY, 2217 Shattuck Avenue, Berkeley, California 94704

PATHEON BOOKS, RANDOM HOUSE, INC., 201 East 50 th street, New York, New York 10022

PARENTS: MAGAZINE PRESS, 52 Vanderbilt Avenue, New York, New York 10017

PATTY-IAR PUBLICATIONS, LTD., Mountain View, California PENDELI PUBLISHING COMPANY, P. O. BOX 1666, Midland, Michigan 48640

POLARIS PRESS, 16540 Camellia Terrace, Los Gatos, California 95030

PRENTICE-HAIL, INC., Englewood Cliffs, New Jersey 07632

G. P. PUTNAM'S SONS, P. O. Box 50, East Rutherford, New Jersey, 07073

RAND MCNALIY, P. O. Box 7600, Chicago, IIlinois 60680

REGIS COLIEGE, West 50th Avenue and Lowell Boulevard, Denver, Colorado 80221

RMI FILM PRODUCTIONS, INC., 4901 Main Street, Kansas City, Missouri 64112

SCHI,ITZ BREWING COMPANY, 235 West Galena Street, Milwaukee, Wisconsin 53201

WARREN SCHLOAT PRODUCTIONS, INC., 150 White Plains Road, Tarrytown, New York 10591

SCHOIASTIC BOOK SERVICES, 904 Sylvan Avenue, Englewood, New Jersey 07632 
SCOTT EDUCATION, 5 Lower Westfield Road, Holyoke, Massachusetts 01040

CHARLES SCRIBNER'S SONS, 597 Fifth Avenue, New York, New York 10017

SOCIETY FOR VISUAL EDUCATION, INC., 1345 Diversey Parkway, Chicago, Illinois 60614

THE SOUTHWEST NETWORK, 1020 B street, Suite 8, Hayward, California

SPOKEN ARTS, 310 North Avenue, New Rochelle, New York 10801 STECK-VAUGHN COMPANY, BOX 2028, Austin, Texas 78767

TEACHERS COLLEGE PRESS, 1234 Amsterdam Avenue, New York, New York 10027

TEACHING RESOURCES FILMS, Station Plaza, Bedford Hills, New York 10507

UNIVERSTTY OF MICHIGAN, Ann Arbor, Michigan 48106

UNIVERSITY OF NOTRE DAME PRESS, Notre Dame, Indiana 46556

UNIVERSITY OF TEXAS PRESS, P. O. BOX 7819, Austin, TeXas 78712

THE VIKING PRESS, INC., 625 Madison Avenue, New York, New York 10022

HENRY Z . WALCK, INC.. 19 Union Square West, New York, New York 10003

WASHINGTON SQUARE PRESS, 630 Fifth Avenue, New York, New York 10020

FRANKIIN WATTS, INC., 845 Third Avenue, New York, New York 10022

WESTERN CINE SERVICE, 312 South Pearl street, Denver, Colorado 80209

WESTMINISTER PRESS, 900 Witherspoon Building, Philadelphia, Pennsylvania 19107

WESTON WOODS, Weston, connecticut 06880 
BIBLIOGRAPHY OF REFERENCES 
BIBLIOGRAPHY OF REFERENCES

\section{Books}

Carter, Thomas P. MEXICAN AMERICANS IN SCHOOL: A HISTORY OF EDUCATIONAL NEGLECT. New York: College Entrance Examination Bcard, 1970.

Forbes, Jack D. MEXICAN AMERICANS; A HANDBOOK FOR EDUCATORS. San Francisco: Far West Laboratory for Educational Research and Development, n.d.

Gorena, Minerva, comp. INFORMATION AND MATERIFLS TO TEACH THE CULTURAI; HERITAGE OF THE MEXICAN AMERICAN CHILD. Austin: Education Service Center Region 13, Dissemination Center for Bilingual Bicultural Education, 1972.

HANDBOOK FOR SIMULATED EXPERIENCES IN HUMAN RELATIONS: A TOTAL IMMERSION IN THE HISPANO CULTURE. Denver: School District 12, Adams County, n.d.

Harrington, Mildred P. SOUTHWEST IN CHIIDREN'S BOOKS: A BIBLIOGRAPHY. Baton Rouge: Louisiana State University Press, 1.952 .

IATIN AMERICA; AN ANNOTATED LIST OF MATERIALS FOR CHILDREN. New York: Information Center on Children's Cultures, United States Comittee for UNICEF, 1969.

THE MEXICAN AMERICAN HERITAGE : DEVELOPING CULTURAL UNDERSTANDING. Los Angeles: Teacher Corps: RuralMigrant School of Education, University of Southern California, 1968.

Poblano, Ralph, ed. GHOSTS IN THE BARRIO; ISSUES IN BILINGUAL-BICULTURAL EDUCATION. San Rafae1, California: Leswing Press, 1973.

Spache, George D. GOOD READING FOR THE DISADVANTAGED READER; MULTI-ETHNIC RESOURCES - Champaign, Illinois: Garrard Publishing Co., 1970.

SUBJECT GUIDE TO CHILDREN'S BOOKS IN PRINT. NEW YOrk: Bowker, 1974. 
Sutherland, Zena, ed. THE BEST IN CHILDREN'S BOOKS: THE UNIVERSITY OF CHICAGO GUIDE TO CHIIDREN'S LITERATURE 1966-1972. Chicago: The University of Chicago Press, 1973.

Articles

Blatt, Gloria T. "The Mexican-American in Children's Iiterature," ELEMENTARY ENGLISH, 45: 446-451, April, 1968.

CALIFORNIA LIBRARIAN. The January, 1973 issue is devoted to "Chicano Library Service."

Carranza, Eliu. "Cultural Erosion," GHOSTS IN THE BARRIO; ISSUES IN BILINGUAL-BICULTURAL EDUCATION, ed. RaIph Poblano (San Rafael, California: Leswing Press, 1973), 6l-69.

- "The Gorkase Mirror," THE CHICANOS; MEXICAN AMERICAN VOICES, ed. Ed Ludwig and James Santibanez (Baltimore: Penguin Books, 1971), 223-234.

Cortes, C. E. "Teaching the Chicano Experience," NATIONAL COUNCIL ON SOCIAL STUDIES YEARBOOK, 43: 180-199, 1973.

Dedeaux, Joyce M., and Beverly Redmond. "Reaching out to Bilingual students," ILLINOIS LIBRARIES, 55: 490-492, September, 1973.

Dunn, Sylvia I. "A Brief Annotated Bibliography of Nonbook Materials on the Mexican-American," TEXAS LIBRARY JOURNAL, 49: 213-214+, October, 1973.

Gerez, Toni de. "Books for Miguel," SCHOOL IIBRARY JOURNAL, 45-47+, December, 1967.

Gast, David K. "Minority Americans in Children's Literature," ELEMENTARY ENGLISH, 44: 12-23, January, 1967.

Guerra, Manuel H. "Educating Chicano Children and Youths," PHI DELTA KAPPAN, 53: 313-314, January, 1972.

- "Why Juanito Doesn't Read," CTA JOURNAL, 61: 17-19, October, 1965. 
Larrick. Nancy. "The All-White World of Children's Books," SATURDAY REVIEW, 48: 64-65, September 11, 1965.

Medina, Rodolfo. "Mexican Americans," INSTRUCTOR, January, 1972 .

THE NATIONAL ELEMENTARY PRINCIPAI. The November, 1970 issue is devoted to "Education for the Spanishspeaking."

Psencik, Leroy F. "Teaching the History and Culture of the Mexican American in Social Studies," THE SOCIAI STUDIES, 63: 307-311, December, 1972.

Revelle, Keith. "Audio-Visual Materials for MexicanAmericans," TEXAs LIBRARIES, 33: 35-41, Spring, 1971.

Sandoval, Ralph, and Alleen P. Nilsen. "The Mexican American Experience," ENGLISH JOURNAI,, 63: 61-63, January, 1974 .

Taylor, José. "The Chicano In Children's Literature," CALIFORNIA LIBRARIAN, 34: 38-39, January, 1973.

\section{Government Documents}

Andersson, Theodore, and Mildren Boyer. BILINGUAL SCHOOLING IN THE UNITED STATES. 2v. Washington: Government Printing Office, 1970.

Bureau of Intergroup Relations. GUIDELINES: SCHOOL STAFF PREPARATION IN THE HISTORY, CULTURE, AND CURRENT PROBLEMS OF RACIAL AND ETHNIC MINORITIES. Sacramento: California State Department of Education, March, 1973.

U.S. Commission on Civil Rights. THE EXCLUDED STUDENT: EDUCATIONAL PRACTICES AFFECTING MEXICAN AMERICANS IN THE SOUTHWEST. Report III. Washington: Government Printing Office, May, 1972.

U.S. Commission On Civil Rights. THE UNFINISHED EDUCATION; OUTCOMES ICR MINORITIES IN THE FIVE SOUTHWESTERN STATES. Report II. ashington: Government Printing Office, October, 1971.

U.S. Commission On Civil Rights. MEXICAN AMERICAN EDUCATION STUDY; ETHNIC ISOLATION OF MEXICAN AMERICANS IN THE PUBLIC SCHOOLS OF THE SOUTHWEST. Report I. Washington: Government Printing Office, April, 1971. 


\section{Newspapers}

Juarez, Luis. "Books Fail to Relate to Chicano Children." SAN JOSE MERCURY-NEWS. February 23, 1975, p. 40.

Unpublished Materials

Arnold, R. D. COMPONENTS OF A READING PROGRAM FOR THE MEXICAN AMERICAN CHIID. International Reading Association Cinference Papers, ERIC Document ED 070046 (1971).

Carpio, Virginia A. "A Selected Annotated Bibliography of Literature Dealing With Mexico and Mexican American Subjects for Use by Junior High School Librarians and students." Unpublished research paper, Department of wibrariansinip, San José state University, 1969.

Clarke, J. C. "Content Analysis of Children's Fiction About the Migrant Families in the United states." Unpublished research paper, Long Island University. 1970 .

Egge, Roberta E. "Enrichment Activities for the Elementary School Library to Meet the Needs of the MexicanAmerican Student." Unpublished research paper, Department of Librarianship. San José State University, 1969.

Gast, David K. "Characteristics and Concepts of Minority Americans in Contemporary Children's Fictional Literature." Unpublished doctoral dissertation, Arizona State University, 1965.

Harrison, Judith $M$. "The Effects of a Library Program Upon the Positive Attitudes of Mexican-American and Anglo Children Toward one Another." Unpublished research paper, Department of Librarianship, San José Stace University, n.d.

Liu, Benjamin P. "A Survey of Library Services to Mexican-Americans in Selected Public Libraries in California." Unpublished master's thesis, san José State University, 1968. 
80

Sandoval, Alberto. "Treatment of Contemporary Mexican Americans in Selected Fifth Grade Textbooks." Unpublished doctoral dissertation, University of New Mexico, 1972 .

Sousa, Sister Mary Rose Therese. "Selected Minorities in Juvenile Fiction Since World War II; 1946-1971." Unpublished research paper, Department of Librarianship, San José State University, 1974. 
APPENDIX 
DATA COLLECTION FORM - PRINT

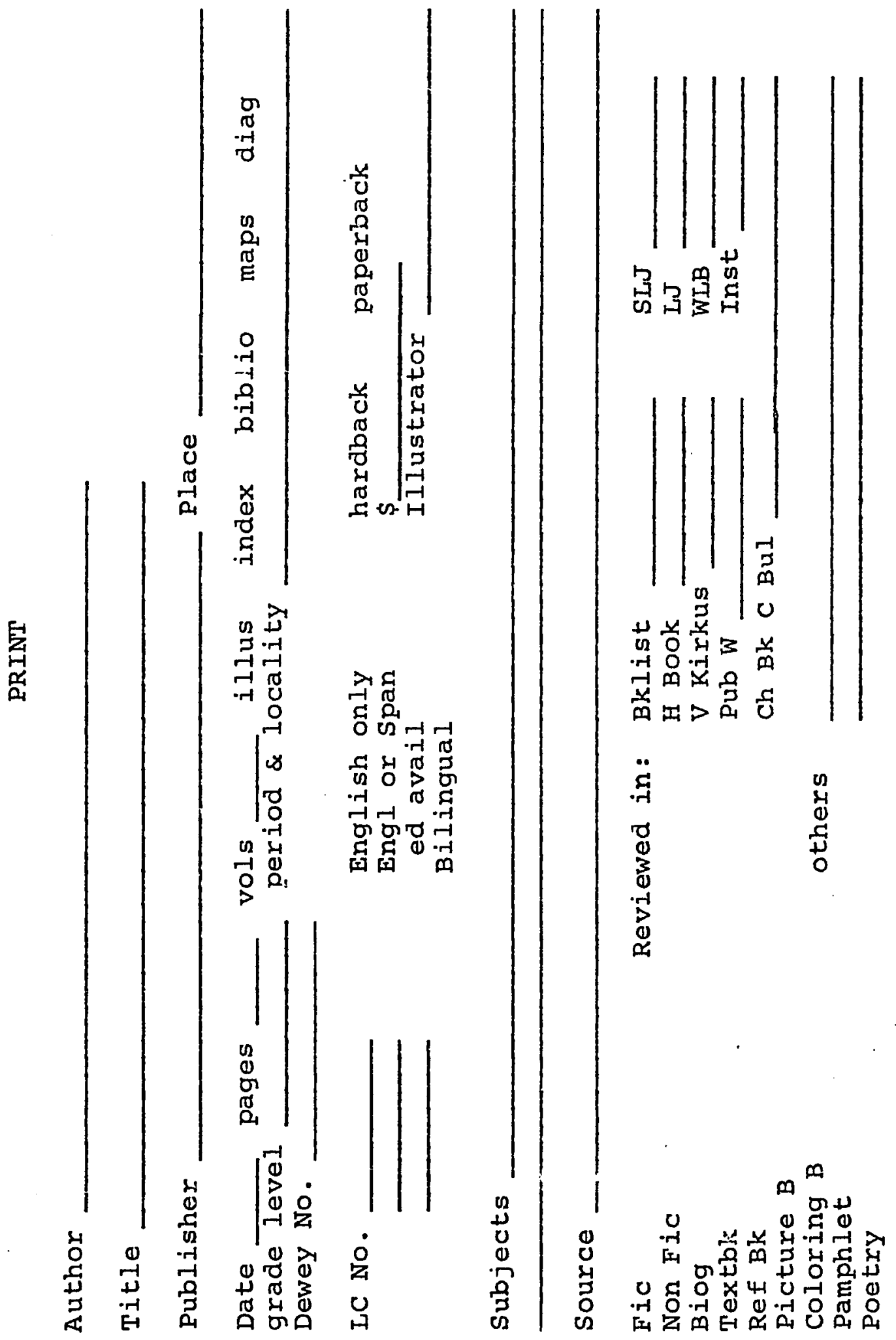


DATA COLLECTION FORM - NONPRINT

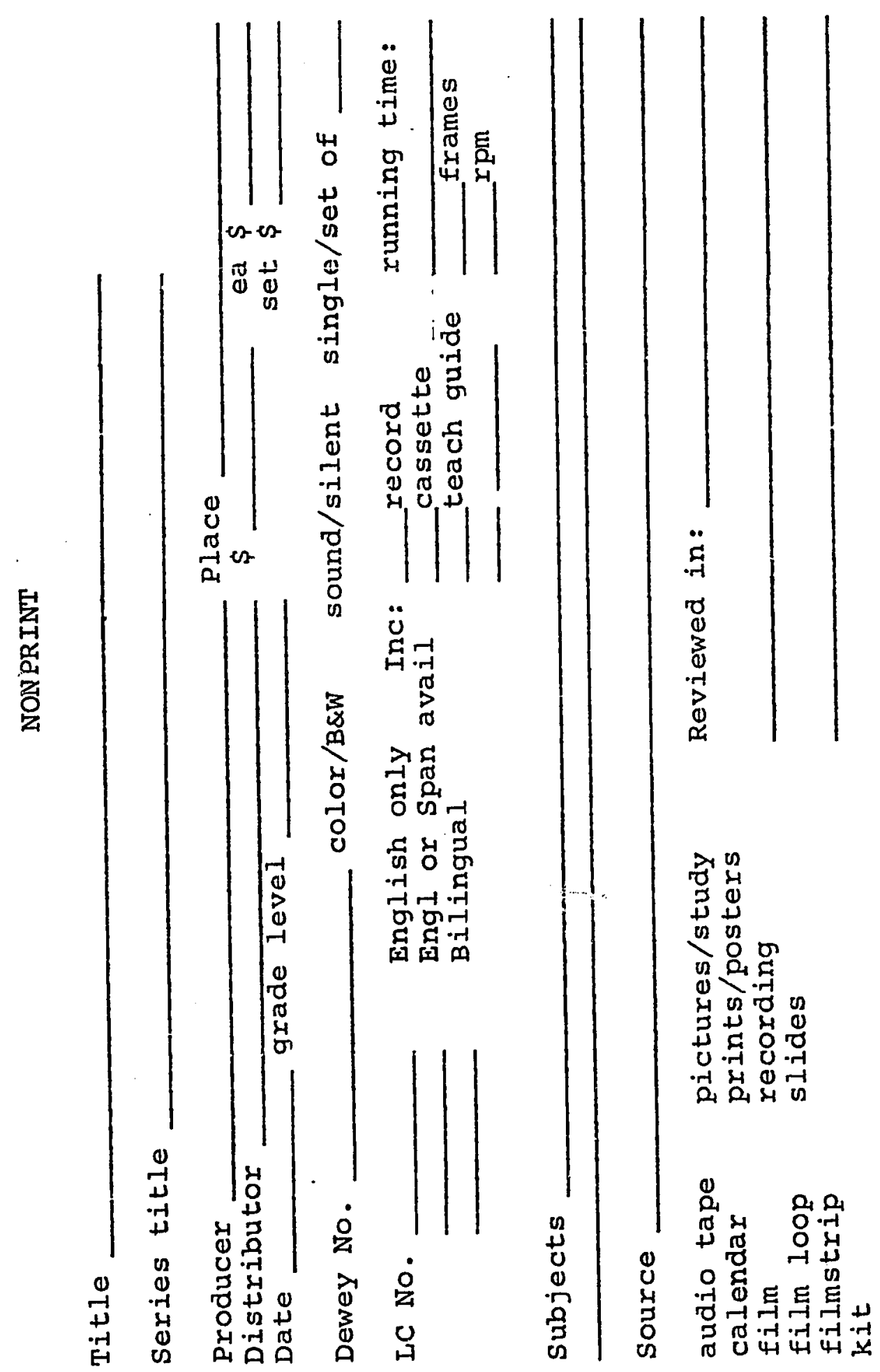


AUTHOR INDEX

Acuña, Rudolph, 41, 42

Franchere, Ruth, 12

Adams, Ruth, 16

Agnew, Edith J., 16

Axford, Roger W. , 12

Ballis, George, 32

Bay Area Bilingual

Education League, 32, 42

Beckett, Hilary, 16

Beilex, Edna, 16

Bernard, Jacqueline, 12

Bishop, Curtis K., 17

Bolognese, Don, 38

Bonham, Frank, 17

Bond, Jean C., 33

Brock, Virginia, 33

Buffler, Esther, 17

Bulla, Clyde R., 17

Bustamante, Charles.

and Patricia, 33

Center For the study of Instruction, 33

Clark, Ann Nolan, 18

Colman, Hila, 18

Cox, William R., 18

Cramer, Kathryn, 15

DeGarza, Patricia, 34

Diaz, Paul, 12

Dobrin, Arncid, 34

Dunne, Mary Collins, 18

Eberle, Irmengarde, 19

Edwards, Jane, 42

Eiseman, Alberta, 34

Ets, Marie Hall, 19, 38

Eyre, Katherine W., 19

Felt, Sue, 19

Fitch, Robert B. and

Iynne, 34

Forsee, Aylesa, 20

Foster, Ed, 20

Franco, John M.. 13

Freeman, Dorothy R., 20

Galarza, Ernesto, 13, 34

Galbraith, clare K., 20

Garcia, Ernest F., 35

Garthwaite, Marion, 21

Gates, Doris, 21, 45

Gee, Maurine H., 21

Greene, Carla, 22

Gutman, Bill, 13

Halladay, Anne M., 22

Hampton, Doris, 22

Hartman, Clinton, 43

Hayes, William D., 22

Hitte, Kathryn, 22

Hood, Flora, 23

Jackson, Robert B., 13

Jaynes, Ruth M.. 39

Jimenez, Emma, 40

Johnson, Philip, 33

Krumgold, Joseph, 23

Laklan, Carli, 23

Lampmañ, Evelyn S., 23

Lexau, Joan M., 24

Lockhart, Iinda z ., 15, 40, 42

Lopez, Arthur, 14

Ludwig, Ed, 15

Mcwilliams, Carey, 38

Madison, Winifred, 24

Marquevich, Pat, 41

Martin, Patricia M., 24, 35

Martinez, Elizabeth, 35

Martinez, Gilbert, 42

Martinez, Rafael V.. 35

Means, Florence, 24

Molarsky, Osmond, 25

Molnar, Joe, 14

Nava, Julian, 14, 25, 26, 36, 43

Newton, Clark, 14 
O'De11, scott, 26

Ormsby, Virginia H., 26, 39

Pinchot, Jane, 36

Politi, Leo, 27

Prago, Albert, 36

Resnick, Seymour, 40

Reuben, Michael, 12

Richards, Kenneth G., 12, 14

Robinson, Benelle H., 28

Rocha, Angie, 15

Ruiz, Ramon, 37

Rydberg, Ernie, 28

Santibañez, James, 15

Schaefer, Jack, 28

Schweitzer, Byrd Baylor, 28

Serfozo, Mary, 39

Shackelton, Peggy, 41

Shaftel, George, 35

Spiegel, shelly, 41

stanek, Muriel, 43

Steiner, Stanley, 36

Stinson, Adele, 15, 40, 42

Sullivan, Mary W.. 43

Summers, James I., 28

Taylor, Florance, W., 29, 30

Taylor, Theodore, 30

Tebbel, John, 37

Terzian, James P.. 15

Todd, Barbara K., 30

Tucker, David, 31

Turner, Mary, 37

Van der Veer, Judy, 31

Vasquez, Enriqueta L., 35

Vasquez, Richard, 31

Villasenor, Edmund, 31

Waugh, Julia N.. 31

Weiner, Sandra, 37

Weiss, Karel, 37

White, Florence M., 15

Whitney, Phyllis A., 32

williams, Letty, 40

Young, Bob and Jan, 32, 38 
TITLE INDEX

A ES PARA AMIGO / A IS FOR AMIGO, 15, 40, 42

ACROSS THE TRACKS, 32

ADOBE CITY, 55

THE ALIENATED AMERICAN, 47

AMERICA, THE MELTING POT: MYTH OR REALITY?, 47

AMERICAN FAMILIES, 47

AMERICANS ALI, A NATION OF IMMIGRANTS, 43

AMERICA 'S CHIIDREN, 47

AMIGO, 28

AND NOW MIGUEL, 23, 55, 56

B.A.B.E.L. CALENDAR, 46

BAD BOY, GOOD BOY, 19,48

BALL TWO:. 29

THE BANDIT OF MOK HILL, 23

BARRIO BOY, 13

BASTA: IA HISTORIA DE NUESTRA LUCHA / ENOUGH! THE TALE OF OUR STRUGGLE, 32

BEING A CHICANO, 48

BENITO, 17

BLUE WILLOW, 21,45

BRAVO MARTA : 48

BRIGHT SUMMER, 28

BROWN IS A BEAUTIFUI COLOR, 33

BROWN STUDIES, 54

BUENAS AMIGAS, 49

EL CALENDARIO CHICANO, 46

CALIFORNIA CONFLICT: MIGRANT FARM WORKERS, 49

CALIFORNIANS OF MEXICAN DESCENT, 45

CALIFORNIA'S DAWN, PARTS I \& II, 56

CASE STUDIES IN AMERICAN TEAMWORK, 45, 65

CESAR CHAVEZ, 12

CESAR CHAVEZ, MAN OF COURAGE, 15

CHICANO, Marshall, 57

CHICANO, Mitchell, 57

CHICANO, Vasquez, 31

CHICANO, AMIGO, 21

CHICANO CRUZ, 18

CHICANO FROM THE SOUTHWEST, 57

CHICANO GIRL, 18

CHICANOS; MEXICANS IN THE UNITED STATES, 35

CHICANOS; THE STORY OF MEXICAN AMERICANS, 34

CHICANOS Y CHICANAS PROMINENTES, 63

CHIID OF FIRE, 26 
CHILDREN OF COURAGE; FIVE ORIGINAL AMERICAN ETHNIC TALES, 49 CITIZEN PABLO, 28

COLONIA--THE MEXICAN AMERICAN, 50

THE CONTEMPORARY MEXICAN AMERICAN OF ALL AGES, 63

THE CORN FESTIVAL, 29

THE CORN FESTIVAL, 29
COSTUMBRES DEL OTRO IADO DE IA FRONTERA, 25
THE CULTURE OE THE MEXICAN AMERICANS, 50

CULTURES IN CONFLICT: PROBLEMS OF THE MEXICAN AMERICANS, 41

CUSTOMS ACROSS THE BORDER, 25

LOS DE IA RAZA, 52

DECISION AT DELANO, 57

DIAS FELICES, 25

ERNESTO, MEXICAN AMERICAN BOY, 50

FAMOUS MEXICAN AMERICANS, 14

FAST BREAK, 17

FELIPA: NORTH OF THE BORDER, 58

FIDELIA， 16

THE FRIDAY SURPRISE, 20

FROM TEXAS TO ILLINOIS, 29

GILBERTO AND THE WIND, 30, 50, 58, 65

GILBERTO Y EL VIENTO, 38

GO UP THE ROAD, 23

GOOD-BYE AMIGOS, 32

GRACIELA; A MEXICAN AMERICAN CHILD TELIS HER STORY, 14

THE HANDS OF MARIA, 58

HAPPY DAYS, 25

HENRY: BOY OF THE BARRIO, 58 OF THE HISPANIC AMERICAN, 35 THE HERITAGE AND CONTRIBUTIONS OF
HISPANIC CULTURAL CONTRIBUTIONS, 59

HISPANIC TERITAGE, 59

HISPANIC LIFE IN THE CITY, 59

HISPANO AMERICAN CONTRIBUTORS TO AMERICAN LIFE, 13

HOLD THE REIN FREE, 31

A HOME FOR MEMO, 20

HUELGA ! , 59

HUELGA MARCH, 59

IN THE CITY-THE MEXICAN AMERICANS, 51

JIM PLUNKETT, 13

JUAN PATRICIO, 30

JUANITA, 27

JUST FOR MANUEL, 22 
THE IAND IS RICH, 60

IA LENGUA / THE SPANISH LANGUAGE, 51

LITTLE LEAGUE DOUBLE PLAY, 17

LITTLE RED HEN / IA PEQUENA GALLINA ROJA, 40

IIVING TOGETHER IN AMERICA, 64

A LONG TIME COMING, 32

MACHO:, 31

MAKERS OF AMERICA, 41

THE MALDONADO MIRACLE, 30

MANANA IS NOW; THE SPANISH SPEAKING IN THE UNITED STATES, 34

MANUEL, YOUNG MEXICAN AMERICAN, 22

MARIA, 24

MARIA LUISA, 24

MARIO; A MEXICAN BOY'S ADVENTURE, 21

MELINDA'S CHRISTMAS STOCKING, 39

MEXICAII SOUP, 22

THE MEXICAN AMERICAN, 52

MEXICAN AMERICAN: AN EXAMINATION OF STEREOTYPES, 46

THE MEXICAN AMERICAN AND THE UNITED STATES, 33

MEXICAN AMERICAN CHILDREN, 64

A MEXICAN AMERICAN COLORING BOOK, 15

MEXICAN AMERICAN CULTURE: ITS HERITAGE, 60

A MEXICAN AMERICAN FAMILY, 60

THE MEXICAN AMERICAN FROM THE REVOLUTION TO THE PRESENT, 60 MEXICAN AMERICAN HERITAGE, 35

THE MEXICAN AMERICAN HERITAGE AND DESTINY, 61

THE MEXICAN AMERICAN; HIS LIFE ACROSS FOUR CENTURIES, 42

MEXICAN AMERICAN: INVISIBLE MINORITY, 61

MEXICAN AMERICAN PROFILES, 14

MEXICAN AMERICANS, Holt/Ealing, 46

MEXICAN AMERICANS, Moreno, 64

MEXICAN AMERICANS IN THE SOUTHWEST, 34

MEXICAN AMERICANS: PAST, PRESENT, AND FUTURE, 43

MEXICAN AMERICANS: QUEST FOR EQUALITY, 61

MEXICAN AMERICANS: VIVA IA RAZA, 61

MEXICANO AMERICANO CAIENDARIO HISTORICO, 46

MEXICANS, 46

THE MEXICANS IN AMERICA, 36

THE MEXICANS IN AMERICA; A STUDENTS' GUIDE TO LOCALIZED

HISTORY, 38

MIGHTY HARD ROAD; THE STORY OF CESAR CHAVEZ, 15

MIGRANT GIRL, 23

THE MIGRANT WORKERS AND CESAR CHAVEZ, 38

MINORITIES HAVE MADE AMERICA GREAT, PART II, 52

MINORITY YOUTH : ANGIE, 62

MI FAMILIA, 25

MIS AMIGOS, 26

MULTIETHNIC STUDIES IN THE ELEMENTARY CIASSROOM, 41 
MY BROTHER, ANGEL, 16

MY FAMILY, 25

MY FRIENDS, 26

MY HOUSE IS YOUR HOUSE, 35

MYSELF, 26

NAMES AND PIACES, 26

A NEW DAY, 38

NEW FRIENDS FOR PEPE, 22

THE NEW IIFE--IA VIDA NUEVA; THE MEXICAN AMERICANS TODAY, 34 THE NICEST GIFT, 27

NOMBRES $Y$ LUGARES, 26

NORTH FROM MEXICO: EXPLORATION AND HERITAGE, 62

NORTH OF THE BORDER, 62

OID RAMON, 28

ONE LUMINARIA FOR ANTONID, 23

OUR MEXICAN HERITAGE, 42

OUT OF THE MAINSTREAM, 52

OUTSTANDING AMERICANS OF MEXICAN DESCENT, 64

PACO AND HIS PAINTING PALS, 52

PACO'S MIRACLE, 18

PANCHO VILLA REBELS, 43

PARA CHIQUITINES, 40

PEDRO, THE ANGEL OF OLVERA STREET, 27

PERFILES MEXICANO AMERICANOS, 14

PIIGRIMAGE, 53

PINAATA, 53

PINATAS, 33

A PIANE RIDE, 29

PORTRAIT OF A MINORITY: SPANISH-SPEAKING AMERICANS, 53

PRIDE OF ATZIAN; A BILINGUAL SURVEY OF MEXICAN HISTORY, 35

A PROBE INTO MEXICAN AHERICAN EXPERIENCE / UN EXAMEN SOBRE

IA EXPERIENCIA DE LOS MEXICOAMERICANOS, 33

EL RANCHO DE MUCHACHOS, 14

IA RAZA, 42

RAZA CULTURAL EVENTS SERIES, 32

IA RAZA; THE HISTORY OF THE CHICANO, 51

IA RAZA, THE MEXICAN AMERICANS, Multi-Media Productions, 51

IA RAZA; THE MEXICAN AMERICANS, steiner, 36

REACH OUT, RICARDO, 18

RIGHT THUMB, LEFT THUMB, 25

RODRIGO AND ROSALITA, 17

ROSA-TOO-LITTLE, 19

A SANTO FOR PASQUALITA, 18

THE SCHOOI PICNIC, 30

SECRETS AT WHITE OWL, 22 
SI SE PUEDE, 62

THE SILVER CRADLE, 31

SLIDE PRESENTATION BY JEARI B - NUNNELEE, 65

SLIDE PRESENTATION BY REV. JOSEPH TORRES, 65

SMALL HANDS, BIG HANDS; SEVEN PROFILES OF CHICANO MIGRALII WORKERS AND THEIR FAMILIES, 37

SOMETHING SPECIAL, 31

SONG OF THE SWALLOWS, 27

SOUTH BY SOUTHWEST; THE MEXICAN AMERICAN AND HIS HERITAGE, 37

SOY CHICANO; I AM MEXICAN AMERICAN, 34

SPANISH AMERICAN CHILEREN'S SONGS, 65

SPANISH AMERICAN LEADERS OF 2OTH CENTURY AMERICA, 54

SPANISH-AMERICAN POETRY; A BILINGUAL SELECTION, 40

THE SPANISH AMERICANS OF NEW MEXICO, 53

SPANISH-SPEAKING ANERICANS, $6 \frac{1}{2}$

SPANISH-SPEAKING HEROES, 12

SPANISH-SPEAKING PEOPLE HAVE HELPED TO BUILD AMERICA, 55

STAF IN THE WILIOWS, 19

THE STORY OF THE MEXICAN AMERICANS; THE MEN AND THE IAND, 42

THE STORY OF THE SPANISH-SPEAKING AMERICAN, 54

STRANGERS IN THEIR OWN LAND; A HISTORY OF MEXICAN

AMERICANS, 36

SUPERMEX; THE LEE TREVINO STORY, 13

TEJANOS, 20

TELL ME, PLEASE! WHAT'S THAT?, 39

TERESITA OF THE VALLEY, 24

TOO MUCH DOG, 20

A TRADITIONAL VOICE IN THE BARRIO, 36

TREASURES FOR TOMAS, 16

TRES CASAS, TRES FAMILIAS, 16

TRINA'S BOXCAR, 24

TWENTY-ONE CHIIDREN, 26

TWENTY-ONE CHILDREN PLUS TEN, 26

UNDER THE MASK: AN ANTHOLOGY ABOUT PREJUDICE IN AMERICA, 37 UP FROM EL PASO, 12

THE VERY GOOD NEIGHBORS, 19

VICTOR, 20

VIVA CHICANO, 17

VIVA LA CAUSA: THE MIGRANT LABOR MOVEMENT, 54

VIVA IA RAZA: THE MEXICAN AMERICAN EXPERIENCE IN THE SOUTHWEST, 5.5

VIVA IA RAZA : : THE STRUGGLE OE THE MEXICAN AMERICAN

PEOPLE, 35

VOICE OF IA RAZA, 63

VOICES FROM THE SOUTHWEST, 12

UNA VOZ TRADICIONAL DEI BARRIO, 36 
WE, TOO, BELONG: AN ANTHOLOGY ABOUT MINORITIES IN AMERICA, 37

WELCOME, ROBERTO! / BIENVENIDO, ROBERTO!, 39

WHAT IS A BIRTHDAY CHILD?, 39

WHAT IS A MIGRANT?, 30

WHAT'S WRONG WITH JULIO?, 39

WHERE'S LUIS?, 30

YO, 26

YO SOY CHICANO, 63

YOU CAN'T MAKE IT BY BUS, 28 